\title{
Bibliography on HIV/AIDS in Ethiopia and Ethiopians in the Diaspora: The 2010 Update
}

\author{
Helmut Kloos ${ }^{1}$, Paul J. Converse ${ }^{2}$, Mesfin Samuel Mulatu ${ }^{3}$, Damen Haile Mariam ${ }^{4}$ Yibeltal Assefa ${ }^{5}$
}

\section{Introduction}

This is the eighth update of the bibliography on HIV/AIDS in Ethiopia, which has been published annually since 2003. All the seven previous issues included published and unpublished research on HIV/AIDS and related health conditions and issues, including other sexually transmitted infections, tuberculosis, and socioeconomic, behavioral and policy as well as risk behavior, gender-based violence, family planning, and relevant health policy and interventions. This update extends the bibliography to cover references not listed in previous updates, both publications and presentations that appeared in 2010 and those that were missed by earlier updates. Following the format of the 2009 Update, this issue presents new references under the same eight main headings, as follows: earlier bibliographies on HIV/AIDS and related health and socio-economic issues, basic biomedical research, epidemiological, social, and behavioral research, treatment, care and clinical research, prevention research, health services and health policy research, health informatics, monitoring, and evaluation research, and HIV/AIDS research on Ethiopians in the diaspora. Similarly, Section 1 lists earlier bibliographies on topics related to HIV/AIDS in Ethiopia and Section 10 lists of selected websites. The text preceding the reference listing not only highlights representative studies in their respective categories, but also addresses issues and questions that continue to emerge as part of the changing HIV epidemic and expanding interventions. In this update we are giving particular attention to the up scaling of antiretroviral treatment, ART in the country and the expansion and reorganizing of the antiretroviral (ART) delivery services and related issues. In this issue, we are cross-referencing some references in different sections to provide more comprehensive coverage of the epidemiological, treatment, care, prevention and health informatics issues addressed in the same publications.
We used the same methods as in the previous updates to identify and catalog the references. Thus, all new references appearing in 2010 were searched in major databases, including PubMed/MEDLINE, CINAHL, Social Work Abstracts, Sociological Collection, EconLit and POPLINE using the key words "Ethiopia and HIV", Ethiopia and AIDS", "Ethiopia and reproductive health", "Ethiopia and sexual behavior" and, to identify publications on Ethiopian immigrants in Israel, "Ethiopia and Israel". Second, journals that were not indexed by these database systems, such as the Ethiopian Journal of Health Development and the Ethiopian Journal of Health Sciences, were manually reviewed for relevant abstracts. In this update, we have included abstracts from major national and international conferences on public health, including the 1) Annual 2010 Conference of the Ethiopian Public Health Association, 2) 2010 International AIDS Conference, Vienna, 3) International Conference on Global Health and the CROI, APHA and AEA conferences. Additional online searches were made on websites of major national and regional HIV/AIDS resource centers, such as http://www.etharc.org, and international organizations (e.g. http://www.unaids.com). Lastly, we again included graduate theses and dissertations prepared in different departments of Addis Ababa University.

This update includes 391 citations, somewhat increased compared to the 2009 update; 143 are articles, 133 conference or workshop presentations, 92 master's theses or doctoral dissertations, 22 unpublished reports by the Federal Ministry of Health, World Health Organization, UNAIDS, or other international or national nongovernment organizations, and 1 is a book [by OSSREA].

\footnotetext{
${ }^{1}$ Department of Epidemiology and Biostatistics, University of California, Medical Center, San Francisco, San Francisco, CA 94143, USA;

${ }^{2}$ Center for Tuberculosis Research, Johns Hopkins University, School of Medicine, Baltimore, MD 21231, USA; ${ }^{3} 4169$ Idlewood Parc Courtm, Tucker, Georgia 30084, USA;

${ }^{4}$ School of Public Health, College of Health Sciences, Addis Ababa University, P.O. Box 32812, Addis Ababa, Ethiopia;

${ }^{5}$ Monitoring and Evaluation Department, National HIV/AIDS Prevention and Control Office, Addis Ababa, Ethiopia
} 
A International Conference on AIDS Abstracts mentioning Ethiopia

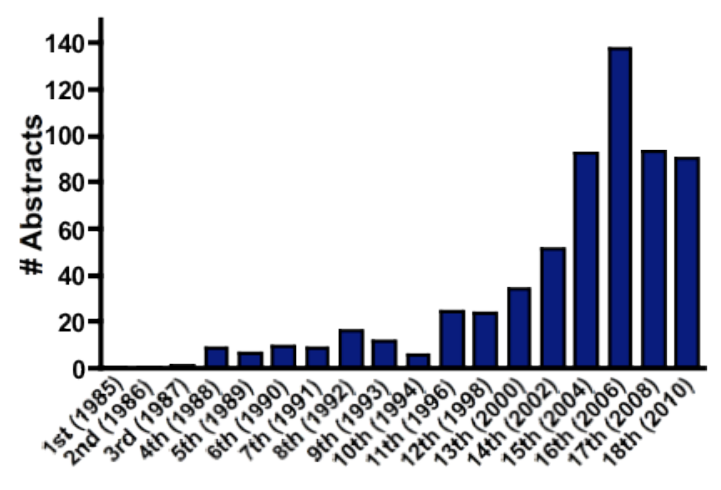

Conference and Year
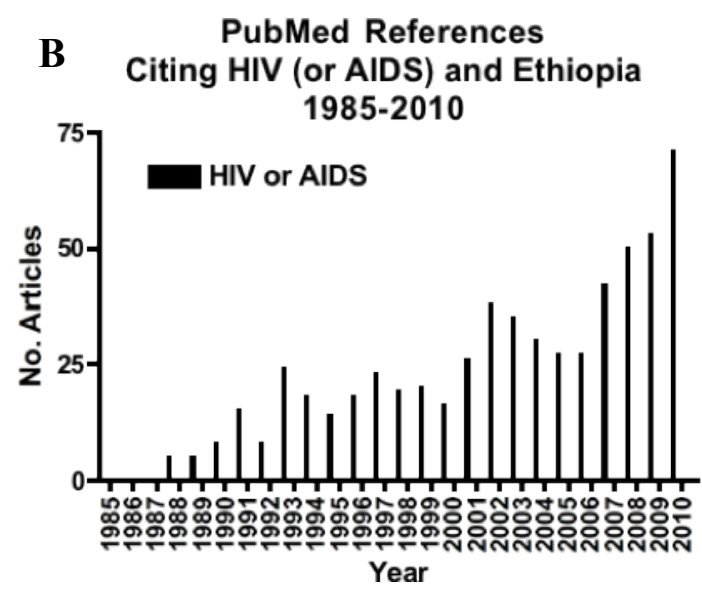

Figure 1: Presentations at the International Conference on AIDS (A) and Publications cited in PubMed (B) concerning Ethiopia and HIV or AIDS. The increase in presentations in recent years now seems to be followed by an increase in material becoming full-length manuscripts. The highest number of presentations (137) was in Toronto in 2006; conferences located in Bangkok, Mexico City, and Vienna all had 90 presentations*.

*A. Conference locations: 1st (Atlanta, 1985), 2nd (Paris, 1986), 3rd (Washington, 1987), 4th (Stockholm, 1988), 5th (Montreal, 1989), 6th (San Francisco, 1990), 7th (Florence, 1991), 8th (Amsterdam, 1992), 9th (Berlin, 1993), 10th (Yokohama, 1994), 11th (Vancouver, 1996), 12th (Geneva, 1998), 13th (Durban, 2000), 14th (Barcelona, 2002), 15th (Bangkok, 2004), 16th (Toronto, 2006), 17th (Mexico City, 2008), 18th (Vienna, 2010).

\section{PubMed References citing Ethiopia}

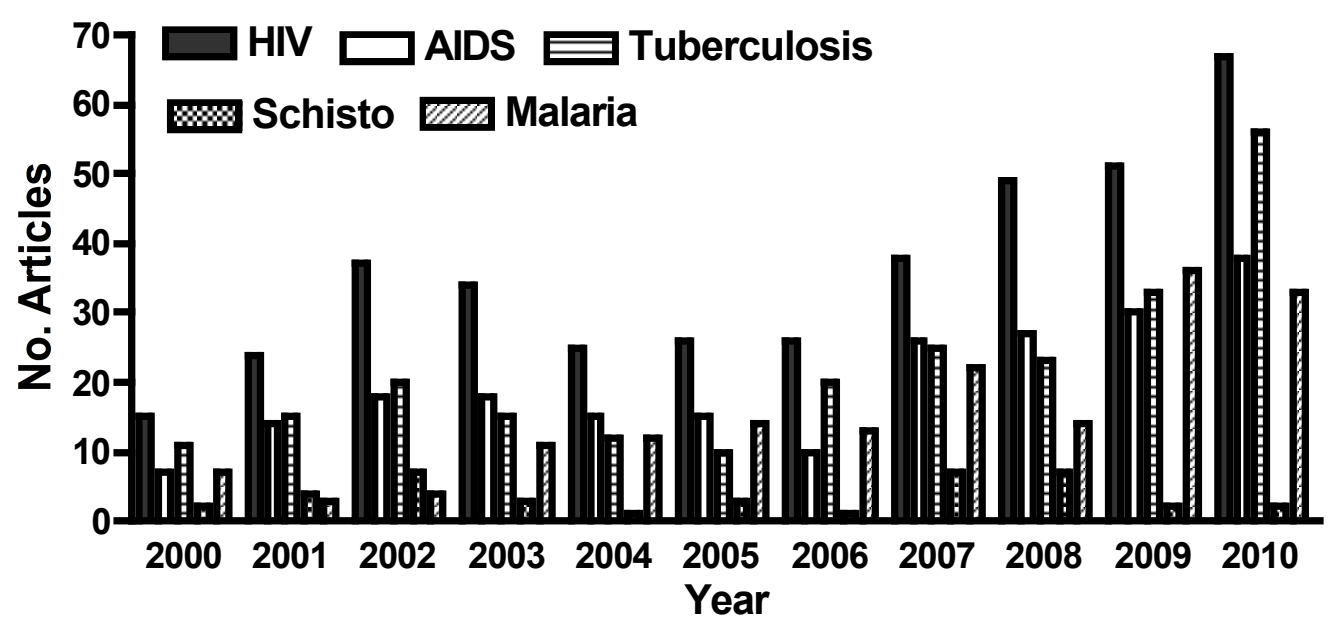

Figure 2: In 2009, there was a large increase in the number of publications concerning HIV, AIDS, and/or tuberculosis and Ethiopia. Again, only 2 publications concerned schistosomiasis and there was a slight decrease in papers concerning malaria, from 36 to 33 .

Basic Biomedical Research

There was a modest increase compared to last year in the number (24) and also the percentage $(6.1 \%)$ of basic laboratory-based biomedical research studies in this update. Of these, 19 (79.2\%) were published articles, 3 $(12.5 \%)$ were master's theses, and $2(8.3 \%)$ were conference abstracts. Among the topics covered in these studies were those related to drug resistance in either tuberculosis or HIV. While multi-drug resistant (MDR)
TB remained low in new Addis Ababa patients tested in 2006 (Agonafir et al. (2010)), MDR-TB in retreated patients had nearly tripled to $71 \%$ compared to the report by Wolde Meskel et al. Ethiop. Med J. 46:219-225 (2008) in patients tested in 2002. Testing patients in Gondar, however, Mekonen et al. (19) found no MDRTB in frozen patient samples. Only the abstract of this paper was available and the time frame could not be determined. These studies all used classical drug 
susceptibility culture testing (DST) methods. Abebe et al. (1) reviewed new molecular methods for DST. These methods have been deployed at St. Peter's TB Hospital and more timely reports could be useful in evaluating the course of the TB epidemic. Eight papers concerned the diagnosis by various methods of human and bovine TB. The latter has yet to be reported in HIV-infected Ethiopians, although the potential would seem to be great. Two papers concerned another opportunistic pathogen of HIV patients, Leishmania donovani. It is to be hoped that the abstract and thesis on ART virological failures will soon be developed into full manuscripts. Finally, we also would urge the Ethiopian Medical Journal find the means to publish their articles online to ensure greater information access and cost savings. Many libraries no longer have non-electronic journal subscriptions.

\section{Epidemiological, Behavioral, Socioeconomic and Cultural Research}

In this update, we slightly modified the heading of this section to give due attention to socioeconomic factors, particularly poverty as a driving force of the HIV epidemic in Ethiopia, particularly among commercial sex workers and street children. With $80(20.5 \%)$ of all 391 references, this section continues to be the largest, although it has become relatively smaller compared to the three Intervention categories (Treatment, Care and Clinical, Prevention, and Health Services and Health Policy Research), each of which contains more references this year than last, particularly the Health Services section. This shift indicates a strong response of the research community to the research needs created by the rapid expansion of the health resources as part of the rapid antiretroviral treatment (ART) program. As in previous updates, the most frequently researched issues in the Epidemiological, Behavioral, Socioeconomic and Cultural Research section in 2010 were the prevalence and distribution of HIV, TB and other co-infections, individual and inter-personal risk behavior, socioeconomic, cultural, psychological and structural determinants of risk behavior and HIV/AIDS. We are therefore; describing here mainly issues that remain either understudied or were not addressed in earlier updates. A study of the link between HIV risk, pregnancy risk perception and use of condoms among adolescents provides relevant and scarce information for health education programs targeting youth (43). Of the many studies that continued to focus on high-risk females and youth, three studies reported on sexual relations between girls and older men, a subject addressed by numerous studies in other sub-Saharan African countries and a risk factor contributing to generally higher HIV prevalence in young females (28). Research showing an association between lower virginity values among female university students with high value given to boy/girl friend relationships can guide health education messages on the consequences of liberalization of sex (11). A new aspect of sexuality in youths was examined by Magadi (54), whose analysis of Demographic and Health Survey (DHS) data for Ethiopia and another 19 sub-Saharan countries revealed that orphans and adolescents in households with HIV-infected adults initiated sexual activities earlier and were more likely to be infected with HIV.

Other new and understudied issues include the relationship between climate change, migration and HIV infection (14), which may have predictive value in analyzing the heterogeneous distribution and apparent diffusion of HIV in the rural Ethiopian population; predisposing factors for sexual violence against females among prisoners (58); high prevalence of oral sex $(9.2 \%)$ and anal sex (4.3\%) among university students (12) and sexual abuse of male street children (69). A comparison of extensive studies on another harmful traditional practice-female genital mutilation- shows that its prevalence decreased from $61 \%$ in 1997 to $46 \%$ in 2007 in all regions except Afar and Somali, where infibulations continues to be widely practiced (48). Persistence of high levels of HIV-related stigma was indicated by a survey of teachers in government and private schools in Addis Ababa shows that most teachers did not intent to teach about HIV/AIDS in the future (47). Useful information on issues surrounding discriminative inheritance and property activities impacting on HIVaffected women is presented in an abstract which also provides a website interested women in 12 East African nations, including Ethiopia, can consult (52).

Several studies focused on pregnancy outcomes, the dilemma mothers face in regard to whether they should breast-feed, and continuing challenges of meeting patients' needs in perinatal programs. Eshete and Wassie (34), examining the multi-factorial nature of pregnancy outcomes, concluded that infection with HIV, refusal to be HIV-tested, malaria infection and having a husband who is a driver, illiteracy of the mother, and rural residence were significantly associated with low birth weight. A study of the risk perception and practice of breast feeding by HIV-infected mothers (49) points out the conflict facing mothers in deciding whether or not to breast feed in light of the possibility of HIV transmission and stigma attached to avoiding breast feeding. High contraception needs expressed by many VCT attendees (25) emphasize the persisting need for the integration of maternal and HIV prevention programs.

\section{Impacts Research}

Twenty-two references were included in the Impacts Section, slightly fewer than in the 2009 update. Most studies examined the impacts of HIV/AIDS on orphans and vulnerable children (OVC) $(3,6,10,11,12,17,21)$, fertility desire and decision making of PLWHA $(7,13,14,20)$, and psychological and quality of life impacts $(2,4,5,9,10)$. The socioeconomic status and functions of orphans and vulnerable children (OVC) in the family setting was discussed by two studies. Whereas 
one study argued that OVC are basically a burden to families affected by HIV/AIDS (6), another study considered them to be essential for the coping of such families (3). Several studies reported on mental disorders among TB/HIV co-infected orphans (9), general wellbeing and educational achievement $(10,11)$, as well as the heavy work loads many OVC carry (21). Two studies examined experiences with and modeling of reintegrating OVC into society $(12,17)$. Further research will be required to comprehensively assess the socioeconomic functions, assets and liabilities of HIV-infected and affected OVC in the household setting to provide information on their specific needs and the needs of the guardians for further community-based and external support. Among the studies on psychological and quality of life impacts of HIV in the general population, only the one by Abera (4) considered stage of infection; hospital patients with mean CD4 counts above 200 cells $/ \mathrm{mm}^{3}$ had better social functioning and mental health and those adhering to ART had higher quality of life scores overall. The finding by Deribew (9) that TB/HIV co-infected individuals had significantly higher risk of common mental disorders has implications for the development of socioeconomic livelihood support programs. All five studies on fertility desire were prepared as Master's theses $(7,8,13,14,20)$. Additional research on fertility desire and family planning decisions by PLWHA is urgently needed because of their impact on future epidemiological, demographic and social characteristics of Ethiopia. Studies considering the perception and functional role of HIV symptoms in the decision of individuals and families whether or not to have children, shown by other researchers to be a major factor, will be particularly needed. The other impacts of HIV and TBmaternal and neonatal mortality $(1,16,18)$, armed conflict (15), and drought (19), although examined in studies presented in earlier updates, are inadequately understood and also warrant further research.

\section{Health Services and Health Policy Research}

We identified $75(19.2 \%)$ ) references as studies dealing with health services and health policies, representing twice as many as in last year's update, apparently due to the increasing need to inform and evaluate the rapidly expanding ART program for the achievement of optimum outcomes. Tesfaye et al. (69) described the structural development of the early phase of the program and Assefa et al. (4-7) summarized recent accomplishments. Among the issues that have received increasing attention by researchers during the last five years are the development of human health resources and task shifting with the objective of scaling up the capacity of the health services to meet the rapidly increasing demands for counseling, testing and treatment services towards the goal of achieving universal access to these services $(6,7,70)$. Interview surveys with providers and AIDS patients and review of records in 23 health center and 32 hospital ART service centers in all regions revealed that in spite of the 10 -fold increase of HIV testing between 2005 and 2008, only $61 \%$ of the positive patients were linked to chronic care immediately after being tested and that attrition increased from $18 \%$ in 2005 to $26 \%$ in 2008 . The main factors in poor linkage and retention were fear of stigma, transport cost, feeling healthy and using traditional medicines, with food insecurity also contributing low retention (7). Further studies will be required to evaluate the out-transfer of AIDS patients from hospitals to health centers nearer their homes for chronic care as part of ART scale-up to guide activities and programs aiming at improving treatment outcomes and patient retention. Although task shifting from higher qualified to lower qualified health workers has been described in literature covered by recent HIV/AIDS Updates, there is still lack of information on the link between task shifting, ART outcomes and patient retention, considered to be one of the most critical issues for the long-term success ART program (6).

Several studies provide evidence that the Ethiopian Health Extension Program, which is the cornerstone of both the provision of primary health care in rural areas and also the increasingly employed task shifting strategy in the delivery of HIV/AIDS services from scarce medical doctors to community-based health workers, is effective. An evaluation of the contribution of community health workers in Ethiopia, Malawi, Namibia and Nigeria showed that they can contribute effectively and inexpensively to deliver HIVAIDS services in rural and underserved communities if the necessary working environment can be created (13). Moreover, better antenatal care use and a higher rate of postnatal visits were achieved in communities with high rates of visits by health extension workers (32), and the Ethiopian Society for Obstetricians and Gynecologists, in close partnership with the Ministry of Health, is planning to develop community-based maternal and neonatal health by promoting awareness of obstetrics/gynecology problems and care, self-care, health seeking behavior, and strengthening access to mother and neonatal services (69). The cost-effectiveness of community health workers has been documented. One study calculated the cost of successfully treating each smear-positive TB patients to be only $37 \%$ of such treatment by general health workers (15). Moreover, health extension workers were similarly functional and competent in antenatal and postnatal care provided in one health post, although they lacked in delivery, newborn care and technical skills (22. These achievements need to be replicated in other communities to provide more evidence that the health extension program is off to a promising start and to alleviate doubts about its effectiveness expressed by one investigator (38). The general consensus of these and other investigators is that greater attention needs to be given to training and in-service refresher courses, supervision and timely supply of medical equipment and supplies to further increase the functionality and competence of extension community health workers. 
REPEATED (See earlier Paragraph) There is a need to improve the management of health information in health posts to increase the efficiency of the health extension program as indicated by a survey of 60 health posts in Tigray Region (63). Four Ministry of Health publications presenting guidelines for a framework for linking health provider-initiated counseling and testing (PICT) (52) and health training packages for HCT $(43,44)$ and the TB, malaria and HIV control program (53) are essential for ART scale-up implementation. Addisse et al. (2) described the progress made by 35 community service organizations toward developing and implementing a HIV and AIDS workplace policy. Another publication bearing on HIV/AIDS policy suggested the incorporation of community-based care into the national continuum of care package (42).

The mobilization, functionality and impact of other community-based health resources, both health workers employed by the health services and volunteers, is described in this update by more studies than before. Of the former, peer educators were found to be an essential component of prevention programs among mobile migrant populations (No. 54 in Prevention Section), case managers or "expert patients" effective promoters of ART adherence (nos. 4 and 28 in Treatment Section), and dispensers of contraceptive pills and condoms in VCT sessions (25). These authors proposed that community counselors also be employed to administer injectaible contraceptives as in many other developing countries to increase the effectiveness of integrated family planning/VCT services. Para-social workers are underdeveloped health resource for the care of HIVorphans and vulnerable children in sub-Saharan Africa. Strengthening of the social workforce is acutely needed in Ethiopia with its large orphan population. A collaborative training program of para-social workers between Ethiopian, Tanzanian and Nigerian universities also promises to generate south-to-south technical assistance $(9,37)$. Five studies reported that the participation of volunteer groups strengthened different HIV/AIDS programs. One study found youth groups to be effective empowerment and advocacy groups which had gained a voice at decision making (nos. 9 and 48 in Prevention Section) and another one described the role of mother support groups in promoting ARV prophylaxis and facility-based deliveries among mothers (No. 27 in Treatment Section). Support given by the Ethiopian Orthodox Church to guardians of orphans and vulnerable children (No. 18, Treatment Section, No. 58 in Prevention Section) and the challenges faced and burden carried by families and other relatives and friends of AIDS patients on chronic care (No. 37, Treatment Section) are promising, but understudied approaches to providing care. Four studies of the impact of malnutrition and socioeconomic status on PLWHA, in addition to those in the Prevention Section, reflect the concern over the impact of persisting food insecurity on voluntary care givers. Weiss et al (No. 62, Treatment Section) estimated that nutritional needs of PLWHA with symptoms being at least twice as high as of PLWHA without symptoms due to their weakened immune system. Maes (39) questioned the sustainability of health care voluntarism in view of the deepening food and financial crisis in Ethiopia and other poor countries and the assumption that local communities are a major source of "untapped moral and social energy". Although community extension workers and several other types of community health workers are being paid in Ethiopia, more research is required on the various issues surrounding the demands placed on and the capacity of volunteers working in community-, organization- family-based anti-AIDS activities and projects to evaluate the sustainability of voluntarism.

Several studies examined the contribution of traditional burial societies (Iddirs) to HIV/AIDS programs. These community-based organizations are increasingly functioning also as indigenous health insurance providers, helping to provide low-cost and effective home and community-based chronic care for HIV/AIDS patients and their families $(57,73,75)$. The generally high demand for iddir membership, team spirit and their capacity to be self-supporting financially make iddirs sustainable, a critical quality of community organizations $(12,57)$. One pilot program showed that palliative care can reduce stigma and discrimination, increase acceptance and use of VCT, improve PLWHA wellbeing, improve household economic conditions of beneficiaries, and increase community support of iddirs (73). Evaluation of that iddir-supported palliative care program, which is linked to local health facilities in 14 major cities, shows that it reduced stigma and discrimination of PLWHA and vulnerable children, increased use of VCT for HIV, improved the well-being of PLWHA, improved the economic stability of affected families and orphans, and increased community support for iddirs (73).

The rapid expansion of the ART delivery system in Ethiopia has been a remarkable achievement considering the logistic challenges and infrastructure problems. By March 2010, the latest month covered by the Ministry of Health's monthly HIV Care and ART Updates, 183,254 AIDS patients were receiving ART from 535 treatment sites (54), a 9-fold increase since February 2006, a few months after free treatment was provided and when the Ministry of Health first issued monthly reports on ART uptake nation-wide. The success of the program is also revealed by the enrollment in the ART program of a socio-economically representative segment of the population, including many poor people (26). On the provider side, however, persistence of high attrition of health workers in regional communities points out the need for greater support of health personnel working in rural areas (28). Additional forces in health manpower attrition, including the pull of the private sector and of international HIV/AIDS partners, are examined by

Ethiop J Health Dev 2011;25(1) 
several studies in the Health Informatics, Monitoring and Evaluation Section. Further studies are needed on health manpower attrition in the public health sector to identify deficiencies in manpower development, with the objective of strengthening human health resources in the regions, particularly rural areas. Another persisting impediment to health services development and accessibility of ART and TB services is the cost to users accessing these services. Costs ranging from $33-40 \%$ of annual household income were reported for pre-treatment and treatment of HIV and TB, with even higher costs for treatment of TB (72). Another study estimated the costs to patients and their escorts to be seven times higher than the cost incurred to the public health system (46). The authors of these two studies suggested possible costcutting measures through early diagnosis of HIV through a more effective referral system and efficient screening of suspects, and the provision of free diagnostic services, alternative care providers.

\section{Prevention Research}

Although there is some overlap between some prevention, treatment and health services issues, particularly in the integration of prevention of mother-tochild transmission (PMTCT), family planning and ART programs, and the involvement of patient and facility factors in adherence and patient retention, research cited in this section is of a predominantly preventive nature. Of the 72 references included in this section, more than a quarter dealt with young people and gender issues (20 references), prevention of mother-to-child transmission (PMTCT) HIV prevention (11 references), counseling and testing (10 references), and condom use and social marketing (9 references). Three studies summarized recent achievements by youth-led advocacy and empowerment groups in supporting HIV prevention for youth $(9,48,62)$, one study each reported favorable attitudes and increasing demand for STI health services by rural youth (53) and university students (60), and another on the development of a program for the enhancement of reproductive health and rights for female university students (65). Similarly, girls' and anti AIDS clubs were reported to improve communication on sexuality among high school students and with parents (57). A survey of youth behavior and socioeconomic characteristics bearing on HIV and STI risk among 10,080 adolescent boys and girls in seven regions concluded that few young people had received information on sexual or reproductive health or puberty from parent, their school and the health services, boys in particular obtaining information from friends; the many young people living away from parents should have better access to health services, social networks and safety nets; programs should provide skills to young men on how to prevent violence in marriage and place greater emphasis on marital transmission of HIV; youth centers should be staffed equitably by males and females to encourage more females to participate in more sexspecific programs; and the potential of religious institutions for implementing youth educational and development activities should be explored (28). The UNESCO publication International Technical Guidance on Sexuality, which provides advice for developers and implementers of school-based sexuality education programs, has been introduced in some Ethiopian schools as a resource for sexuality education and HIV prevention, but research is required on the development of partnerships between stakeholders at the school and community levels (4). It has also become evident that the design, implementation and evaluation of behavioral and socioeconomic interventions among youth will have to be more rigorous and include HIV testing of study populations. A review of 1,200 studies on HIV prevention among youth in sub-Saharan Africa, including Ethiopia, concluded that the great majority of interventions remain weak, largely because of the failure to include biological markers necessary for the evaluation of programs (27).

Three studies referenced in this update presented encouraging evidence that gender equity for HIV prevention and violence may be achieved in different urban populations through community-based communication activities and if inequitable gender norms can be changed towards greater male involvement in programs $(43,46,61)$. Similarly, a PMTCT pilot project showed that male participation can be significantly increased by challenging traditional social norms and by making health services more welcoming to men (37). In another pilot intervention, Asefa and Mitike (6) noted facility-based deficiencies in the low quality of PMTCT. A well designed PMTCT project addressing some of these and other problems resulted in more HIV-positive women delivering in hospitals and having their CD4 counts tested, as well as in larger percentages of male partners tested for HIV (4). A city-wide review of health records in Addis Ababa revealed that although the proportion of partners tested for HIV decreased between 2004 and 2009 and of young children on ART (nevirapine) in 2007 had decreased by nearly half by 2009 (zidovudine), the infection rate among all ANC attendants decreased from $10.5 \%$ in 2004 to $4.6 \%$ in 2009 , reflecting the larger number of women being tested (51). Further studies will be required to inform in the scaling up of the PMTCT programs in smaller regional and district towns and rural areas, which depress MTCT rates in Ethiopia to one of the lowest world-wide.

According to the 2010 UNAIDS Report (59), condom use among males was still less than $10 \%$ and near zero among women in Ethiopia in 2009, among the lowest rates in sub-Saharan Africa (UNAIDS 2010). National PMTCT coverage in 2010 was estimated below $20 \%$ and ANC coverage less than $30 \%$ (59). Four studies provided encouraging information about increasing accessibility, effectiveness and patient satisfaction with ANC/PMTCT services in different health facilities and programs $(5,6$, 21.13, 21, No. 41 in Health Services Section). One study 
described a novel approach (apparently the first time to be used in Ethiopia) to distributing condoms at gas stations, where house maids and other females lacking direct access to health facilities can obtain them (5). Two other publications reported that intended and actual condom use by low-illiterate rural females were strongly related to psychosocial factors, including self-efficacy $(14,15)$, indicating the need for stepped-up health promotion and counseling activities in rural areas, in addition to increasing the accessibility of condoms.

Ten studies reported on the development and impact of health promotion, communication and VCT programs. They included studies of the behavioral changes achieved with effective HIV prevention messages among illiterate rural women (12), modeling of intended use of VCT among school teachers (59), the lower use of mobile VCT services, but higher HIV prevalence among tested women than men (42), high disclosure rates of positive HIV status by female ART patients to partners (30), HIV risk reduction with a prevention education program involving drama, role play and drawings to break community silence about HIV/AIDS and stimulate discussions (64), and assessment of the extent, barriers, and improvements in communication on sexual and reproductive health issues among parents and their children (19,31). Encouraging results of pilot projects in stigma reductions were reported by Desta and McCrossan $(26,43)$ who used a participatory-based intervention and the latter community conversations, a participatory strategy sensitizing communities to and empowering communities to reduce risk behavior which was first introduced in Ethiopia about 10 years ago (71). Morrone et al. (54) informed on a peer education method using trans-cultural mediators among Somali pastoral nomadic populations in Ethiopia, Somalia and other African countries.

Six studies focused on HIV/AIDS prevention among high-risk and hard -to-reach groups. Two studies examined HIV prevention options and economic support for commercial sex workers (49, 17); Tadele (65) addressed safety concerns and practices of men having sex with men. Desta (26) reported the low knowledge, high HIV denial rates and resistance to using condoms, and low use of prevention services among Afar pastoralists. Any progress in HIV/AIDS reduction among these and other pastoralists demands the development of culturally appropriate interventions $(26,54)$. Although health workers are usually not included among high-risk HIV groups, two studies on their occupational exposure are cited here since they indicate the need for stepping up preventive measures among this group. A retrospective study of HIV exposure by health personnel in health facilities revealed that even though $68.5 \%$ of them had been exposed in the past, only $18.4 \%$ used post-exposure prophylaxis due to lack of information, fear of stigma and discrimination, lack of understanding the need for and support in reporting (No. 58, Treatment Section).
Another study found similar exposure rates and that nearly half of the health workers reported unsatisfactory supply of infection prevention materials, and a similar proportion had unfavorable attitudes toward standard precautions such as recapping needles, indicating the need for strengthening supervision and training (No. 61, Health Services Section).

Increasing attention is given by researchers to the potential of and need for improved nutrition in ameliorating HIV infection. Besides general nutrition, adequate intake of vitamin $\mathrm{A}$ is receiving increasing attention by researchers as an HIV suppressant. One study reported lower serum protein, albumin and serum vitamin A serum levels in HIV-infected than noninfected women pregnant and non-pregnant women (No. 59, Epidemiology Section). Production and consumption of vegetables which contain high levels of vitamin A was encouraged by two studies $(1,2)$. The high prevalence of food insecurity among PLWHA (69, No. 62, Epidemiology Section) is a stark reminder of the impediments in ART adherence and outcome. Another urgent, but understudied approach to improving general health levels in populations at risk of HIV infection and reducing the risk of co-infections in HIV-infected persons involves the integration of water, sanitation and hygiene into HIV/AIDS programs (10).

Four studies dealt with positive and negative impacts of traditional surgical procedures. Gebremedhin (33), reviewing 18 Demographic and Health Surveys in subSaharan Africa, including Ethiopia, found a strong association between male non-circumcision and HIVrisk. WHO and UNAIDS have developed a manual and training package for safe male circumcision and an African NGO has been training clinicians in Ethiopia and five East African countries (7). Two studies provided new information on harmful traditional practices, one showing a statistically significant association between surgical procedures in the oropharyngeal area and HIV infection (52). The other study used community conversation and dialogue to promote the abandonment of female genital mutilation/cutting (FGM/C) among different ethnic groups. This latter study provided information for better understanding of the process of behavioral change within communities and the interaction and contribution of different local and outside actors (24). These insights can facilitate the scaling up of strategies to encourage abandonment of $\mathrm{FGM} / \mathrm{C}$ and should be followed up with evidence-based studies.

\section{Treatment, Care, and Clinical Research}

Sixty-one of the $358(17 \%)$ references in this update were classified in this category. Researchers again addressed a wide range of clinical and non-clinical issues in the provision of treatment and care of patients with AIDS and related diseases, adherence and treatment outcome. Most studies dealt with treatment outcome, survival and mortality, mostly of AIDS patients, but also TB/HIV and 
HIV/Leishmania donovani double infections and TB $(3,5-$ $7,9,14,16,31,33,36,47,48,52,53,56,57)$ and adherence to treatment $(4,13,21-24,32,46,59-61)$. Although the incidence of death of persons on ART is not well documented in Ethiopia and other African countries, the peaking of mortality among patients newly enrolled in treatment programs, their overall beneficial impacts and major determinants of mortality, such as low CD4 counts, nutritional status, having advanced disease, WHO stage IV, and poor adherence to ART, have been reported by many studies. Some of the studies in this update identified new and understudied factors in ART-related mortality. Of the two studies comparing ART outcomes between hospital and health centers, one reported no differences in mortality and loss to follow-up (3) and the other found significantly better outcomes at health centers (9). These findings indicate that the rapid ART scale-up nation-wide has not compromised the quality of treatment at health centers, which are serving increasing numbers of PLWHA. Another study found age group above 45 years and drug regimen $1 \mathrm{~b}$ (stavudine, lamivudine and nevirapine) to be significant predictors of mortality from AIDS (6). An 8-year retrospective study of successfully treated tuberculosis patients associated older age, sex (males) and non-farmers with higher mortality (16). Shaweno $(52,53)$ and Getahun $(25,26)$ examined treatment outcome of tuberculosis patients on DOTS, the former reporting the synergistic impact of HIV/TB on mortality. The beneficial influence of HIV/AIDS testing on treatment-seeking behavior of tuberculosis patients (8) adds to the importance of testing centers in stemming the epidemic. Poor tuberculosis treatment outcomes in a health center in southern Ethiopia were attributed to the lack of focused measures (48) and major deficiencies of TB treatment in six TB clinics in Afar Region were associated with deficient staffing, supervision, laboratory supplies and patientprovider relations (29), all problems which have been reported from other pastoralist areas in Ethiopia.

The 2010 WHO treatment guidelines, which recommend earlier initiation of ART, at a CD4 count of $<350$ cells $/ \mathrm{mm}$ (rather than the old standard of CD4 $<200$ cells $/ \mathrm{mm}$ ), increases the number of Ethiopians medically eligible for antiretroviral therapy by about 30\% (No. 70, Prevention Section). They will need to be considered in the planning and management of individual ART delivery centers and ART outcomes, utilization and coverage. The resulting further increase in the number of PLWHA who will be put on ART and the possibility of transmitted drug resistance point out the need for stepped up surveillance to maintain high drug efficacy. The rapid increase in ART had not revealed transmitted drug resistance above the 5\% WHO threshold level in newly infected individuals in Addis Ababa in 2008, referred in our 2009 HIV/AIDS Update. However, there is mounting evidence that drug resistance is gradually developing in Africa (65), following the trend in the industrialized countries.
Although high adherence rates in ART have been reported from most hospitals studied (28), loss to followup continues to be of concern in health facilities, reflecting limited capacity and quality of some health services and levels of stigma towards PLWHA. A 6-year HIV cohort study reported that a quarter of all patients were lost to follow-up before starting ART, particularly those presenting with less advanced disease stage and living in rural areas, that PLWHA increasingly reported earlier, and that the mortality rate of those who did start treatment declined over time $(36,47)$. In addition to the previously reported patient- and facility-related factors in losses to follow-up, level of readiness for ART, which is associated with level of apprehension and hopelessness, was reported to be a strong predictor of adherence to ART (61). While one study found access to ART to alleviate stigma among PLWHA (55), another study reported that some HIV-infected persons missed taking ARTs because of self-perceived stigma, contributing to the high non-adherence rate in that health facility (22). The finding of a study that defaulting from ART was significantly associated with lack of knowledge about the consequences of discontinuing treatment, doubts about and loss of interest in ART and use of alternative medicine indicate the need for continued counseling during chronic treatment (23). The fact that all patients missing doses in a hospital population were due to either forgetfulness, lack of food, being too busy, transportation problems and being away from home (46) indicate the precarious living conditions of this population. Addressing the issue of possible over-reporting adherence by self-reporting, one study concluded that adherence measurement may be standardized by using existing routine patient data (No. 8, Health Informatics Section) and another study developed a Bayesian Network model to predict adherence trends in the affected population (No. 26, Health Informatics Section). Several studies reported the beneficial role of facilitators of ART adherence, including the utilization of case workers (4, 32) and parents influencing their HIVpositive children. Particularly promising is the utilization of case workers or 'expert patients', who were accredited in one intervention trial with increased ART uptake and adherence, and reduced loss to follow-up (4). Another study reported the beneficial effect of palliative care on ART adherence (20). Talman et al. (56) found that children had higher ART default rates than adults and that most losses to follow-up were due to administrative errors (duplicate charts, incorrect address, etc.), death and changing place of residence, indicating the need for improved documentation and collaboration with community-based organizations. Information on referred patients for use by destination facilities appears to be similarly deficient, as indicated by a study of TB screening and referral linkage among HIV patients attending central and regional hospitals (35), requiring further studies of patient referral practices. 
Six studies focused on issues related to chronic care and support of orphans and vulnerable children (18), the training and use of para-social workers to assist and support vulnerable children and families (No. 37, Health Services Section), the challenges faced by the many poor care givers serving terminally ill patients (37), the development of urban gardens to help HIV-infected females on ART cope socioeconomically (49), improving the nutritional status of infected mothers (62) and the use of holy water (13), which not only has spiritual benefits for terminally ill patients, but may also constitute a risk factor by delaying antiretroviral treatment. Other six studies examined treatment effectiveness and clinical and immunological parameters of HIV, TB and HIV/Leishmania donovani co-infections (31, 33, 52, 53, and 64). Several studies dealt with psychosocial problems of PLWHA on ART experience, particularly the prevalence and causes of mental disorders (39, also No. 9 in the Impacts Section) and their quality of life (6, 14), PMTCT using antiretroviral prophylaxis for infants (49), and clinical aspects and risk factors, particularly malnutrition in mothers and children $(57,62)$. Mental health, quality of life and nutritional issues remain understudied in view of the prevalence and magnitude of these problems among HIV-infected and affected persons in Ethiopia.

One issue which has been of considerable concern since the scale-up of ART world-wide, the impact of treatment and improvement in health on the sexual behavior of PLWHA on treatment, has received little attention in Ethiopia so far. Longitudinal studies in several other subSaharan countries showed that their risk behavior does not significantly increase during the course of treatment and even decreased in one study. While these findings alleviate concerns about the continuation of high-risk sexual activities by patients on ART, additional longitudinal studies are needed to examine this relationship in the Ethiopian context. A retrospective study of this issue in Ethiopia in 2010 found that a large proportion (37\%) of 1,781 AIDS patients on ART engaged in risky sex during the period three month prior to the study (17).

\section{Health Informatics, Monitoring and Evaluation Research}

In this update, $34(8.7 \%)$ covered a growing diversity of health information and/or monitoring and evaluation issues. Most studies dealt with the introduction of new information technology, teaching methods and mainstreaming programs $(3,8,12,21,23,24,28,29,33,35)$. A community score card process was implemented which facilitates and measures accountability of all organizations providing HIV/AIDS related social services and promotes discussions of challenges and opportunities with multiple stakeholders (3). Development of HIV/AIDS prevention messages for illiterate rural women (no. 14 in the Prevention Section), the issuance of revised provider-initiated testing and counseling guidelines for HIV/AIDS service centers (nos. 50,51 in the Health Services Section) and implementation on a strategic framework for linkages and referral HCT and chronic HIV services (nos. 40,41 in the Health Services Section), as well as the use of routine data to measure ART adherence (8) all can contribute to render prevention, treatment and care services more effective. The development and implementation of an innovative information technology which significantly reduces data transfer and report processing time (28), integrated programming (29) and video conference-based distant learning between institutions in Ethiopia and other countries (25) promise to have applications beyond HIV/AIDS programs.

The rapid scale-up of ART services in Ethiopia was discussed by several publications in addition to those listed in the Health Services, Prevention, and Treatment Section. They focused on patterns and impacts of HIV/AIDS service utilization and scaling up of services $(16,20,23,27,31,36,37)$. A particularly relevant study analyzed the impact of the response of Ethiopia and four other African countries to the HIV epidemic over the last 25 years using micro-simulation and DHS data; the results provide decision makers with quantitative information on the long-term impact of their investment and thus to build their case for the continuation of HIV/AIDS funding (20). One study evaluated the potentially negative impact of the rapid up-scaling of the national ART program on human resources (staff number and composition, in-service training, supervision, time allocation, and motivation), service delivery and medical products for other priority health care services. Results from interviews with health workers in 57 primary care facilities in four regions revealed improved services in nearly all categories (No. 10 in Health Services Section). An evaluation of PEPFAR's (President's Emergency Plan for AIDS Relief) impact on major health parameters in Ethiopia and other sub-Saharan countries showed that while the under-5 mortality rates decreased significantly in PEPFAR focused countries, no significant changes were recorded in the malaria-related death rate, TB mortality rate, and infant immunization rates (27). These results point to the need for further strengthening of the HIV/TB/malaria initiatives and integration of HIV/AIDSrelated activities into primary health care. A cost analysis of the PEPFAR-funded orphan and vulnerable children programs in Ethiopia shows that costs per child decrease with the scaling up of programs (32). Further research is required to comprehensively evaluate the effectiveness and quality of institutionalized orphan care, which has been associated with various management problems in several other sub-Saharan countries. But the absence of a national human resources policy for the health policy may hamper the performance of international aid agencies. One study pointed out the need for better coordination of multiple donor preferences and capacity building of local organizations receiving funds from the Global Fund (No. 31, Health Services Section).

Ethiop J Health Dev 2011;25(1) 
Relatively few studies examined in 2010 the effectiveness and quality of programs $(5,17,18,30,32)$. A review of all ANC records in Addis Ababa revealed that while VCT increased sharply and HIV prevalence decreased more than half among attendees and from $14.3 \%$ to $8.2 \%$ among their exposed infants between 2004 and 2009, PMTCT service utilization remained below 45\% and VCT among partners decreased from $6.1 \%$ to $5.3 \%$. These data and the fact that PMTCT service utilization rates are significantly lower in smaller towns and rural areas (No. 48, Health Services Section), represent a major challenge for achieving the country's goal of a "HIV-free generation by 2020" (23). One study evaluated the potentially negative impact of the rapid up scaling of the national ART Program on human resources (staff number and composition, in-service training, supervision, time allocation, and motivation), service delivery and medical products for other priority health care services. Results from interviews with health workers in 57 primary care facilities in four regions revealed improved services in nearly all categories (No. 10, Health Services Section).

\section{Diaspora Research}

Following the pattern of research listed in the Diaspora Research section in earlier updates, most of the 13 references included here pertain to clinical and epidemiological research. Seven studies focused on tuberculosis $(1,3-7,11,12)$, one each on HIV/TB and HIV/Leishmania donovani co-infections (4, 7,) and two on HIV/AIDS $(2,9)$. Stigma and breastfeeding $(10,13)$ and epidemiological differences between native-born African-Americans and African immigrants (8) were addressed by the remaining studies.

\section{Section 1. Earlier Bibliographies on HIV/AIDS and Related Health and Socio-Economic Issues}

1. Alemayehu E, Belachew T. Health science student research at Jimma University: Abstracts of all public health faculty graduate student research projects (1996- 2004). Addis Ababa: Addis Ababa University Press, 2005.

2. Alemayehu E, Belachew T. Health science student research at Jimma University: Abstracts of all medical sciences faculty graduate student research projects (1991- 2004). Addis Ababa: Addis Ababa University Press, 2005.

3. Center for Research Training and Information on Women in Development (CERTWID). An annotated bibliography of gender issues in Ethiopia. Vol. 1 \& 2. CERTWID, Addis Ababa University, 2004.

4. Converse PJ, Wuhib T, Mulatu MS, Kloos H. Bibliography on HIV/AIDS in Ethiopia and Ethiopians in the Diaspora. Ethiop J Health Dev 2003;17(Special Issue):33- 85.

5. Converse PJ, Mulatu MS, Kloos H, Haile Mariam D, Wuhib T, Pankhurst A. Bibliography on HIV/AIDS in Ethiopia and Ethiopians in the Diaspora: The 2005 update. Ethiop J Health Dev 2006;20(1):60.
6. Converse PJ, Kloos H, Mulatu MS, Mariam DH, Haddis A. Bibliography on HIV/AIDS in Ethiopia and Ethiopians in the Diaspora: The 2008 update. Ethiop J Health Dev 2009;23(1):73-94.

7. Ethiopia, Ministry of Finance and Economic Development, Population Department. An Annotated Bibliography of Population and Reproductive Health Researches in Ethiopia, 2002-2007. Addis Ababa, December 2008, 156 pages.

8. Ethiopian Public Health Association (EPHA). Extracts of MPH theses works by EPHA-sponsored graduate students in public health. EPHA, Addis Ababa, 2004.

9. Kloos H, Mulatu MS, Converse PJ. Bibliography on HIV/AIDS in Ethiopia and Ethiopians in the Diaspora: 2003 Update. Ethiop J Health Dev 2004;18(1):57-64.

10. Kloos H, Assefa Y, Haile Mariam D, Mulatu MS, Converse PJ. Bibliography on HIV/AIDS in Ethiopia and Ethiopians in the Diaspora: The 2007 Update with an Emphasis on the ART Scale-Up. Ethiop J Health Dev 2008;22(1):71-95.

11. Mulatu MS, Kloos H, Converse PJ, Wuhib T, Pankhurst A. Bibliography on HIV/AIDS in Ethiopia and Ethiopians in the Diaspora: The 2004 update. Ethiop J Health Dev 2005;19(1):64-85.

12. Mulatu MS, Kloos H, Converse PJ, Haile Mariam D. Bibliography on HIV/AIDS in Ethiopia and Ethiopians in the Diaspora: The 2006 update. Ethiop J Health Dev 2007;21(1):70-91.

\section{Section 2. Basic Biomedical Research}

This section covers laboratory-based biomedical research, including studies on HIV structure, replication, and host immune responses; co-infection with other agents; development and testing of laboratory procedures; and other related laboratory studies.

1. Abebe G, Paasch F, Apers L, Rigouts L, Colebunders R. Tuberculosis drug resistance testing by molecular methods: Opportunities and challenges in resource limited settings. J Microbiol Methods 2010;84:155-160.

2. Abebe M, Doherty TM, Wassie L, Aseffa A, Bobosha K, Demissie A, et al. Expression of apoptosis-related genes in an Ethiopian cohort study correlates with tuberculosis clinical status. Eur J Immunol 2010;40:291-301.

3. Agonafir M, Lemma E, Wolde-Meskel D, Goshu S, Santhanam A, Girmachew F, et al. Phenotypic and genotypic analysis of multidrug-resistant tuberculosis in Ethiopia. Int $\mathrm{J}$ Tuberc Lung Dis 2010;14:1259-1265.

4. Aichelburg MC. Predictive value of IGRAs in HIVinfected individuals. Int $\mathrm{J}$ Tuberc Lung Dis 2010;14:S50-S51.

5. Ameni G, Aseffa A, Hewinson G, Vordermeier M. Comparison of different testing schemes to increase the detection Mycobacterium bovis infection in 
Ethiopian cattle. Trop Animal Health Prod 2010;42:375-383.

6. Ameni G, Desta F, Firdessa R. Molecular typing of Mycobacterium bovis isolated from tuberculosis lesions of cattle in northeastern Ethiopia. Veterinary Record 2010;167:138-141.

7. Ameni G, Vordermeier M, Aseffa A, Young DB, Hewinson RG. Field evaluation of the efficacy of Mycobacterium bovis Bacillus Calmette-Guerin against bovine tuberculosis in neonatal calves in Ethiopia. Clin Vaccine Immunol 2010;17:15331538.

8. Ayele W, Mekonnen Y, Messele T, Mengistu Y, Tsegaye A, Bakker M, et al. Differences in HIV type 1 RNA plasma load profile of closely related cocirculating Ethiopian subtype $\mathrm{C}$ strains: $\mathrm{C}$ and $\mathrm{C}^{\prime}$. AIDS Res Hum Retroviruses 2010;26:805-813.

9. Berhan Y. Age and CD4 count of vertically HIVinfected children at the time of diagnosis: What are independent predictors for being symptomatic and CD4 counts drop? J Trop Pediatr 2010.

10. Beyene D, Lumc Franken K, Yamuah L, Aseffa A, Wiker HG, Kolk A, et al. Serodiagnosis of tuberculous lymphadenitis using a combination of antigens. J Infect Dev Countries 2010;4:96-102.

11. Biffa D, Bogale A, Skjerve E. Diagnostic efficiency of abattoir meat inspection service in Ethiopia to detect carcasses infected with Mycobacterium bovis: implications for public health. BMC Public Health 2010;10:462.

12. Ejara ED, Lynen L, Boelaert M, van Griensven J. Challenges in HIV and visceral Leishmania coinfection: Future research directions. Trop Med Int Health 2010;15:1266-1267.

13. Gelanew T, Kuhls K, Hurissa Z, Weldegebreal T, Hailu W, Kassahun A, et al. Inference of population structure of Leishmania donovani strains isolated from different Ethiopian visceral leishmaniasis endemic areas. PLoS Negl Trop Dis 2010;4:e889.

14. Idh J, Abate E, Westman A, Elias D, Janols H, Gelaw A, et al. Kinetics of the QuantiFERON-TB Gold In-Tube test during treatment of patients with sputum smear-positive tuberculosis in relation to initial TST result and severity of disease. Scand J Infect Dis 2010;42:650-657.

15. Isogai H, Mulu A, Diro E, Tekleselassie H, Kassu A, Kimura K, et al. Identification of Candida species from human immunodeficiency virus-infected patients in Ethiopia by combination of CHROMagar, tobacco agar and PCR of amplified internally transcribed rRNA spacer region. J Appl Res 2010;10:2-8.

16. Legesse AA. The impact of deworming on the immune status of HIV positive pre-ART individuals as determined by CD4 T-cell count in Arba Minch, Chencha and Gidole hospitals, southern Ethiopia [MSc thesis]. Dept of Biology: Addis Ababa University 2010 .
17. Legesse M, Ameni G, Mamo G, Medhin G, Bjune G, Abebe F. Performance of QuantiFERON-TB Gold In-Tube (QFTGIT) for the diagnosis of Mycobacterium tuberculosis (Mtb) infection in Afar pastoralists, Ethiopia. BMC Infect Dis 2010;10:354.

18. McNerney R, Wondafrash BA, Amena K, Tesfaye A, McCash EM, Murray NJ. Field test of a novel detection device for Mycobacterium tuberculosis antigen in cough. BMC Infect Dis 2010;10:161.

19. Mekonen M, Abate E, Aseffa A, Anagaw B, Elias D, Hailu E, et al. Identification of drug susceptibility pattern and mycobacterial species in sputum smear positive pulmonary tuberculosis patients with and without HIV co-infection in north west Ethiopia. Ethiop Med J 2010;48:203-210.

20. Mekonnen Y, Geskus B, Hendriks JCM, Messele T, Miedema F, Coutinho RA, et al. Low baseline CD4 counts do not lead to faster HIV disease progression in Ethiopians. 17th Conference on Retroviruses and Opportunistic Infections 2010; San Francisco, CA, USA. Abstract No. 43.

21. Mulugeta M, Mengistu Y, Wolday D. Monitoring of ART virological failure using pooled Nat Strategy. 21st Annual Conference of the Ethiopia Public Health Association; 2010; Mekele, Ethiopia. Abstract No. 5.

22. Novitsky V, Wang R, Lagakos S, Essex M. HIV-1 subtype $\mathrm{C}$ phylodynamics in the global epidemic. Viruses-Basel 2010;2:33-54.

23. Woldearegay HT. Assessment of virological ART failures using a pooled nucleic acid testing (NAT) strategy [MSc thesis]. Dept of Microbiology: Addis Ababa University; 2010.

24. Zewdie T. Reference value of CD4+ T lymphocyte seronegative Ethiopia women [MSc thesis]. Dept of Biochemistry: Addis Ababa University; 2010.

Section 3. Epidemiological, Behavioral, and Socioeconomic Research

This section includes studies on the epidemiology of HIV and other opportunistic infections, AIDS and related diseases, and risk and protective behaviors. It also covers research on the biological, psychosocial, socioeconomic, cultural, structural, and other contextual determinants of HIV transmission and prevention.

1. Abebe G, Deribew A, Apers L, Woldemichael K, Shiffa J, Tesfaye M, et al. Knowledge, health seeking behavior and perceived stigma towards tuberculosis among tuberculosis suspects in a rural community in southwest Ethiopia. PLoS One 2010;5:e13339.

2. Abedela AA. Sexual violence among street adolescents: Exploring the experience of sexually violated female street adolescents: The case of Addis Ketema Sub-City [MA thesis]. School of Social Work: Addis Ababa University; 2010.

3. Abegaz WM. Challenges of female students and their vulnerability to HIV/AIDS in Dessie town 
private TVETs [MOL thesis]. Azusa Pacific University; 2006.

4. Abera MW. Prevalence and associated risk factors of sexual violence among female students in AAU College of Commerce [MA thesis]. School of Social Work: Addis Ababa University; 2010.

5. Adere BA. Determinants of mother-to-child transmission of HIV (MTCT) during pregnancy/labor and delivery: A case-control study [MPH thesis]. School of Public Health: Addis Ababa University; 2010.

6. Agazi A. Assessment of sexual violence and sexually transmitted infections among prisoners aged 15-29 years in Addis Ababa. 21st Annual Public Health Conference of the Ethiopian Public Health Association; 2010; Mekele, Ethiopia. Abstract No. 13.

7. Ahmed HM. The life situation and survival strategy of rural urban female migrants: The case of Dessie Town, South Wollo [MA thesis]. Dept of Social Anthropology: Addis Ababa University; 2010.

8. Ahmed TA. Factors contributing to commercial sex work in Sebeta town [MA thesis]. School of Social Work: Addis Ababa University; 2010.

9. Alemayehu T, Haider J, Habte D. Determinants of adolescent fertility in Ethiopia. Ethiop J Health Sci. 2010;24:30-38.

10. Alemu T, Tadesse H, Kebede D. Explorative assessment of factors predisposing to homosexuality and subsequent HIV infection among orphans and vulnerable children living on the streets of Dilla Town, southern Ethiopia. 21st Annual Conference of the Ethiopan Public Health Association; 2010; Mekele, Ethiopia. Abstract No. 8.

11. Ambaw F, A. M, Gobena T. Boy/girl friend and virginity values, and stigma related to condom among Jimma University students. Ethiop J Health Sciences. 2010;20:169-177.

12. Ambaw F, Mossie A, Gobena TF, Mossie A, Gobena T. Sexual practices and their development pattern among Jimma University students. Ethiop J Health Sciences. 2010;20:159-167.

13. Ambaye IA. Young people and sexuality. 18th International AIDS Conference; 2010; Vienna. Abstract TUPE0724.

14. Asfaw D. Nexus of climate change, migration and HIV/AIDS among rural communities in Blue Nile Basin of Ethiopia: Lessons from ecosystem approaches to health. 18th International AIDS Conference; 2010; Vienna. Abstract TUPE1046.

15. Asfour FR, Chun HM, Bezabih M, Belayneh F, Tetemke T, Abebe Y, et al. A survey of occupational exposures in hospitals in Ethiopia. 17th Conference on Retroviruses and Opportunistic Infections 2010; San Francisco, CA, USA. Abstract No. 579.
16. Asrat SG. Coping with domestic abuse: The case of married women in Addis Ababa [MA thesis]. School of Social Work: Addis Ababa University; 2010.

17. Assefa YB. Beliefs about HIV/AIDS transmission and prevention amon preparatory students in Bahir Dar town, Ethiopia [MN thesis]. Dept of Nursing: Addis Ababa University; 2010.

18. Awoke T, Meseret S. Glimpse of University of Gondar students' sexual behaviors and their perception of susceptibility to HIV/AIDS. 21st Annual Public Health Conference of the Ethiopian Public Health Association; 2010; Mekele, Ethiopia. Abstract No. 7.

19. Ayenew A, Leykun A, Colebunders R, Deribew A. Predictors of HIV testing among patients with tuberculosis in North West Ethiopia: A casecontrol study. PLoS One. 2010;5:e9702.

20. Aynalum AE. Marital divorce in Bahir Dar Town: Major contributing factors in consequences on the spouses [MA thesis]. Dept of Counseling Psychology: Addis Ababa University; 2010.

21. Bekele HB. The nature and effects of emotional violence/abuse against grade eleven female students of Addis Ketema Preparatory School, Addis Ababa [MA thesis]. Dept of Gender Studies: Addis Ababa University; 2010.

22. Bekele TA. Assessment of current sexual activity and risky sexual behavior for HIV infection among Butajira high school students [MPH thesis]. School of Public Health: Addis Ababa University; 2010.

23. Biadglegne F, Belyhun Y, Tessema B. Seroprevalence of human immunodeficiency virus (HIV) among voluntary counseling and testing (VCT) clients in Burie Health Center, West Gojjam, Ethiopia. Ethiop Med J. 2010;48:149-156.

24. Biffa D, Inangolet F, Bogale A, Oloya J, Djonne B, Skjerve E. Risk factors associated with prevalence of tuberculosis-like lesions and associated mycobacteria in cattle slaughtered at public and export abattoirs in Ethiopia. Trop Anim Health Prod. 2011;43:529-538.

25. Bradley H, Tsui A, Kidanu A, Gillespie D. HIV infection and contraceptive need among female Ethiopian voluntary HIV counseling and testing clients. AIDS Care. 2010;22:1295-1304.

26. Burke D, Akwara P. Fear and prejudice still common towards those living with HIV: Evidence from survey-based data. 18th International AIDS Conference; 2010; Vienna. Abstract TUPE0584.

27. Cafo JM. Risk factors and consequences of violence against female high school girls in Harar [MN thesis]. Dept of Nursing: Addis Ababa University; 2010.

28. Debela MM, Worku A. Cross-generational sexual relationship among preparatory school female students in Addis Ababa, Ethiopia. 18th Ethiop J Health Dev 2011;25(1) 
International AIDS Conference; 2010; Vienna. Abstract TUPE0245.

29. Deressa M, Assefa N, Damena M, Alemayehu T, Dessie Y. Risky sexual behavior and contraceptive use among Haramaya University students. 21st Annual Public Health Conference of the Ethiopian Public Health Association; 2010; Mekele, Ethiopia. Abstract No. 20.

30. Deribew A. Distribution of Most-at-Risk Population Groups and their Perceptions Towards HIV/AIDS: A Baseline Survey in Dire Dawa for the Implementation of Mobile HIV Counseling and Testing. Bethesda, MD: Private Sector Program-Ethiopia, Abt Associates; 2009.

31. Deribew A, Abebe G, Apers L, Jira C, Tesfaye M, Shifa J, et al. Prejudice and misconceptions about tuberculosis and HIV in rural and urban communities in Ethiopia: A challenge for the TB/HIV control program. BMC Public Health. 2010;10:400.

32. Deribew A, Hailemichael Y, Tesfaye M, Desalegn D, Wogi A, Daba S. The synergy between TB and HIV co-infection on perceived stigma in Ethiopia. BMC Res Notes. 2010;3:249.

33. Esatu, F., Deyassa N. Sexual violence among house maids and its adverse health outcome in Awassa. 21st Annual Public Health Conference of the Ethiopian Public Health Association; 2010; Mekele, Ethiopia. Abstract No. 15.

34. Eshete A, Wassie B. Adverse pregnancy outcomes and its association with maternal nutrition among laboring mothers in North Wollo, northwest Ethiopia. 21st Annual Public Health Conference of the Ethiopian Public Health Association; 2010; Mekele, Ethiopia. Abstract No. 53.

35. Eticha BT. Syphilis prevalence among patients who visit the ART and VCT centers of St. Paul's Hospital, Addis Ababa [MSc thesis]. Institute of Pathobiology: Addis Ababa University; 2010.

36. Fentaw S, Mekonnen D, Adugna D, Dessale A, Desta K. Prevalence of vulva vaginalis candidiasis among pregnant women attending antenatal care in Addis Ababa, Ethiopia. 21st Annual Public Health Conference of the Ethiopian Public Health Association; 2010; Mekele, Ethiopia. Abstract No. 70.

37. Fikrie Z. Factors associated with perceived continuation of females' genital mutilitation among women in Ethiopia. Ethiop J Health Sci. 2010;20:49-53.

38. Getahun TY. HIV/STI behavioral survey among male and female students in Axum University: A comparitive study, Axum Town, Tigray, northern Ethiopia [MPH thesis]. School of Public Health: Addis Ababa University; 2010.

39. Getaneh A, Medhin G, Shimelis T. Cryptosporidium and Strongyloides stercoralis infections among people with and without HIV infection and efficiency of diagnostic methods for Strongyloides in Yirgalem Hospital, southern Ethiopia. BMC Res Notes. 2010;3:90.

40. Gossa T. Fertility needs among people living with HIV/AIDS in four regional hospitals [MPH thesis]. School of Public Health: Addis Ababa University; 2010.

41. Gouws E, Lyerla R, Garcia-Calleja JM, Barrerre B, Serrano D, Velasquez C, et al. Trends in HIV prevalence and sexual behaviour among young people aged 15-24 years in countries most affected by HIV. Sex Transm Infect. 2010;86 Suppl 2:ii72-ii83.

42. Gubena FW. Seroprevalence of toxoplasmosis and immune profile of HIV infected and non-infected subjects in Bahir Dar [MSc thesis]. School of Pubic Health: Addis Ababa University; 2010.

43. Haile Mariam TA. Exploring the link between HIV and pregnancy risk perception and contraceptive use among youth in Debre Berhan District [MPH thesis]. School of Public Health: Addis Ababa University; 2010.

44. International Group on Analysis of Trends in H. I. V. Prevalence Behaviours in Young People in Countries Most Affected by HIV. Trends in HIV prevalence and sexual behaviour among young people aged 15-24 years in countries most affected by HIV. Sex Transm Infect. 2010;86 Suppl 2:ii72-ii83.

45. Kebebew T. Stigmatizing and discriminatory attitude towards PLHIV among high school students. 18th International AIDS Conference; 2010; Vienna. Abstract THPE0930.

46. Kebede W. Adolescent social networks and sexual practices [MSc thesis]. Akilu Lemma institute of Pathobiology: Addis Ababa University; 2010.

47. Kidane Y, Abebe L, Tura G. School teachers' behavioral intention to teach about HIV/AIDS in schools, using a theory of planned behavior, in Addis Ababa, Ethiopia. 21st Annual Public Health Conference of the Ethiopian Public Health Association; 2010; Mekele, Ethiopia. Abstract No. 11.

48. Kitaw Y, Haile Meskal F, Dejene A. Female genital mutilations (FGM) in Ethiopia: Findings from EGLDAM's follow-up survey 2007 and the role of health professionals. 21st Annual Public Health Conference of the Ethiopian Public Health Association; 2010; Mekele, Ethiopia. Abstract 23.

49. Koricho AT, Moland KM, Blystad A. Poisonous milk and sinful mothers: the changing meaning of breastfeeding in the wake of the HIV epidemic in Addis Ababa, Ethiopia. Int Breastfeed J. 2010;5:12.

50. Lajebo AM. The prevalence of malaria among HIV positive individuals in Wondo Genet, southern Ethiopia [MSc thesis]. Addis Ababa University; 2010.

Ethiop J Health Dev 2011;25(1) 
51. Legesse M, Ameni G, Mamo G, Medhin G, Shawel $D$, Bjune $G$, et al. Knowledge and perception of pulmonary tuberculosis in pastoral communities in the middle and lower Awash Valley of Afar Region, Ethiopia. BMC Public Health. 2010;10:187.

52. Lukera M, White S. Inheritance Legal Network in Eastern and Southern Africa: Responding to HIV/AIDS and discriminative application of inheritance laws through collaborative exchange of knowledge, information and expertise. 18th International AIDS Conference; 2010; Vienna. Abstract THPE0933.

53. Maes KC, Hadley C, Tesfaye F, Shifferaw S. Food insecurity and mental health: surprising trends among community health volunteers in Addis Ababa, Ethiopia during the 2008 food crisis. Soc Sci Med. 2010;70:1450-1457.

54. Magadi M. A cross-national analysis of the association between HIV/AIDS and adolescent sexual and reproductive health in Sub-Saharan Africa. 18th International AIDS Conference; 2010; Vienna. Abstract TUPE0743.

55. Mengistu B. HIV prevalence and associate risk factors among university students, eastern Ethiopia 2009. 18th International AIDS Conference; 2010; Vienna. Abstract TUPE0249.

56. Mitiku TK. Determinant factors affecting contraceptive use among preparatory school students in Addis Ababa. Dept of Nursing: Addis Ababa University; 2010.

57. Mohamed SA. Gender differences in youth sexual behavior and vulnerability to HIV infection in Burayu Zone, Oromia Region [MA thesis]. Dept of Population Studies: Addis Ababa University; 2010.

58. Muleta M, Gerrits T, Both R. Husband's roles in prenatal care in Addis Ababa. 21st Annual Public Health Conference of the Ethiopian Public Health Association; 2010; Mekele, Ethiopia. Abstract No. 57.

59. Mulu A, Kassu A, Huruy K, Tegene B, Assefa D, Yamamoto $S$, et al. Vitamin A deficiency during pregnancy and HIV co-infection in tropical settings of northwest Ethiopia. 21st Annual Public Health Conference of the Ethiopian Public Health Association; 2010; Mekele, Ethiopia. Abstract No. 48.

60. Negassa DF. Major predisposing factors for commiting violence against women: A case of prisoners from Titcha Prison Center, North Shoa Zone, Oromia Region [MA thesis]. Dept of Counseling Psychology: Addis Ababa University; 2010.

61. Negeri EL. Assessment of sexual behavior, attitudes and rik perception about HIV/AIDS among out of school anti-AIDS club members and non-club members youths, Ilu-Abba Bora Zone, western Ethiopia [MPH thesis]. School of Public Health: Addis Ababa University; 2010.

62. Rahlenbeck S, Mekonnen W, Melkamu Y. Female genital cutting starts to decline among women in Oromia, Ethiopia. Reproductive Biomedicine Online. 2010;20:867-872.

63. Ramos JM, Reyes F, Tesfamariam A. Childhood and adult tuberculosis in a rural hospital in southeast Ethiopia: A ten-year retrospective study. BMC Public Health. 2010;10:215.

64. Regassa A, Tassew A, Amenu K, Megersa B, Abunna F, Mekibib B, et al. A cross-sectional study on bovine tuberculosis in Hawassa town and its surroundings, southern Ethiopia. Trop Anim Health Prod. 2010;42:915-920.

65. Robertson K, Liner J, Hakim J, Sankale JL, Grant I, Letendre $S$, et al. NeuroAIDS in Africa. J Neurovirol. 2010;16:189-202.

66. Storla DG, Yimer S, Bjune GA. Can treatment delay be utilized as a key variable for monitoring the pool of infectious tuberculosis in a population? J Infect Dev Countries. 2010;4:83-90.

67. Tadesse S. Harmful traditional practices affecting the lives of young girls and pre-disposing factor to becoming infected with HIV/AIDS: The case of Borena Zone, Oromiya Region of Ethiopia. 18th International AIDS Conference; 2010; Vienna. Abstract TUPE0658.

68. Tajure N. Knowledge, attitude and practice of emergency contraception among graduate female students of Jimma University, southwest Ethiopia. Ethiop J Health Sci. 2010;21:91-97.

69. Tefera G. "Unrecognized victims": Sexual abuse against male street children in Merkato area, Addis Ababa. 18th International AIDS Conference; 2010; Vienna. Abstract TUPE0531.

70. Tegegn AT. The psychological effects of child abuse and neglect during adolescence: The case of Suluta Secondary School [MA thesis]. School of Social Work: Addis Ababa University; 2010.

71. Tesfaye BA. The causes and consequences of female genital mutilation among Muslims: The case of Assaita Town, Afar National Regional State of Ethiopia [MA thesis]. Dept of Gender Studies: Addis Ababa University; 2010.

72. Tessema B, Yismaw G, Kassu A, Amsalu A, Mulu A, Emmrich F, et al. Seroprevalence of HIV, HBV, HCV and syphilis infections among blood donors at Gondar University Teaching Hospital, Northwest Ethiopia: Declining trends over a period of five years. BMC Infect Dis. 2010;10:111.

73. Tilahun D, Assefa T, Belachew T. Knowledge, attitude and practice of emergency contaceptives among Adama University students. Ethiop J Health Sciences. 2010;20:195-202.

74. Tschopp R, Aseffa A, Schelling E, Berg S, Hailu E, Gadisa E, et al. Bovine tuberculosis at the wildlifelivestock-human interface in Hamer Woreda, Ethiop J Health Dev 2011;25(1) 
South Omo, southern Ethiopia. PLoS One. 2010;5:e12205.

75. Tschopp R, Schelling E, Hattendorf J, Young D, Aseffa A, Zinsstag J. Repeated cross-sectional skin testing for bovine tuberculosis in cattle kept in a traditional husbandry system in Ethiopia. Veterinary Record. 2010;167:250-256.

76. Tully DC, Wood C. Chronology and evolution of the HIV-1 subtype C epidemic in Ethiopia. AIDS. 2010;24:1577-1582.

77. Worku DD. Intestinal parasitic infections among HIV seropositive and HIV seronegative patients presented with diarrhea in Gondar, NW Ethiopia [MSc thesis]. Dept of Parasitology: Addis Ababa University; 2010.

78. Yigzaw T, Berhane Y, Deyessa N, Kaba M. Perceptions and attitude towards violence against women by their spouses: A qualitative study in northwest Ethiopia. Ethiop J Health Dev. 2010;24:39-45.

79. Zenab AA. Knowledge, attitude and practice (KAP) toward HIV/AIDS among college students in Jijiga Town [MSc thesis]. Aklilu Lemma Institute of Pathobiology: Addis Ababa University; 2010.

80. Zewde T. Factors affecting acceptance of HIV testing among antenatal care attendees in Ethiopia: With emphasis on role of male partners. Int J Infect Dis. 2010;14:E76-E77.

\section{Section 4. Impacts Research}

This section includes studies on the characteristics and clinical course of HIV infection and opportunistic infections, treatment to AIDS and opportunistic infections, effects and outcomes associated with treatment, clinical and non-clinical care and supportive services provided to people living with HIV/AIDS.

1. Abdella A. Maternal mortality trend in Ethiopia. Ethiop J Health Dev. 2010;24:115-122.

2. Abebe BG. Psychological problems of PLWHA at Fiche town [MA thesis]. Dept of Measurement and Evaluation: Addis Ababa University; 2010.

3. Abebe T, Skovdal M. Livelihoods, care and the familial relations of orphans in eastern Africa. AIDS Care. 2010:1-7.

4. Abera K, Gedif T, Endigawork E, Gebre-Mariam T. Quality of life of people living with HIV/AIDS and on highly active antiretroviral therapy in Ethiopia. Afr J AIDS Res. 2010;9:31-40.

5. Alamirew YA. The psychological experiences of victims of external women trafficking: Gonder town in focus [MA thesis]. Dept of Social Psychology: Addis Ababa University; 2010.

6. Balew G, Worku N, Tilaye T, Huruy K, Fetene T. Assesment of household burden of orphaning and coping strategies by guardians and families with orphans and vulnerable children in Hossana Town, SNNPR. Ethiop Med J. 2010;48:219-228.
7. Debsay AH. Magnitude and factors affecting fertility desire of women living with HIV in Addis Ababa City Administration [MPH thesis]. School of Public Health: Addis Ababa University; 2010.

8. Demeke YZ. Reproductive women with HIV: The experiences of women living with HIV/AIDS in Tinsae PLWHA Assoaciation, Nifas Silk Lafto Sub City [MA thesis]. School of Social Work: Addis Ababa University; 2010.

9. Deribew A, Tesfaye M, Hailmichael Y, Apers L, Abebe G, Duchateau L, et al. Common mental disorders in TB/HIV co-infected patients in Ethiopia. BMC Infect Dis. 2010;10:201.

10. Diro HW. Maternal and paternal absence on emotional care and well being and academic achievement of boy and girl single orphans [MA thesis]. Dept of Social Psychology: Addis Ababa University; 2010.

11. Edossa AK. The interrelationship of safe sex, self esteem and academic achievement of instituitional orphans and non-orphans [MA thesis]. Dept of Counseling Psychology: Addis Ababa University; 2010.

12. Eshetu N, Silva RdSe, Kanamori M, Correa J. Caring program: A multilevel strategy for reintegrating Ethiopian orphans due to HIV/AIDS to society. 138th Annual Conference of the American Public Health Association; 2010; Denver, CO, USA. Abstract No. 224864.

13. Feyissa TR. Reproductive intention and reproductive health care of people living with HIV/AIDS [MPH thesis]. School of Public Health: Addis Ababa University; 2010.

14. Gebre Michael MA. Fertility desire and family planning practice among people living with HIV/AIDS in Hosanna Hospital and Health Center, Hadiya Zone (SNNPR) [MPH thesis]. School of Public Health: Addis Ababa University; 2010.

15. Gele AA, Bjune GA. Armed conflicts have an impact on the spread of tuberculosis: The case of the Somali Regional State of Ethiopia. Confl Health. 2010;4:1.

16. Hogan MC, Foreman KJ, Naghavi M, Ahn SY, Wang M, Makela SM, et al. Maternal mortality for 181 countries, 1980-2008: a systematic analysis of progress towards Millennium Development Goal 5. Lancet. 2010;375:1609-1623.

17. Kanamori M, Eshetu N, Carter-Pokras O, Correa J. Adapting a Social Network Model for Social Reintegration of Vulnerable Children due to HIV/AIDS in Ethiopia. 138th Annual Conference of the American Public Health Association, ; 2010; Denver, CO, USA. Abstract No. 223027.

18. Kebede B, Gebeyehu A, Sharma HR, Yifru S. Prevalence and determinant factors of neonatal mortality in North Gondar, northwest Ethiopia. 21st Annual Public Health Conference of the 
Ehiopian Public Health Association; 2010 Mekele, Ethiopia. Abstract No. 65.

19. Mason JB, Chotard S, Bailes A, Mebrahtu S, Hailey P. Impact of drought and HIV on child nutrition in Eastern and Southern Africa. Food Nutr Bull. 2010;31:S209-218.

20. Smith A, Byrne C, Ogolla C, Degefu Y, Ibramogy F, Walman NP, et al. A participatory approach to assessing the quality of life by people affected by HIV. 18th International AIDS Conference; 2010; Vienna. Abstract WEPE0689.

21. Suleiman EU. Desire for children and challenges of HIV positive men and women: The case of Hawassa [MA thesis]. Dept of Population Studies: Addis Ababa University; 2010.

22. Whetten R, Messer LC, Whetten K, Ostermann J, Pence B, Thielman N. Child labor and orphaned and abandoned children in five less wealthy nations. 138th Annual Conference of the American Public Health Association; 2010; Denver, CO, USA. Abstract No. 219619.

Section 5. Health Services and Health Policy Research This section includes reports on research and programmatic activities that are aimed at expanding and improving the healthcare system, including such issues as expansion of services for people living with HIV/AIDS, health resource economics and management, healthcare staff training, and national as well as international policies, laws, and guidelines for the provision of services and the protection of people living with HIV/AIDS, women, children, and other vulnerable groups.

1. Abebo TA. Assessment of sexual practice and reproductive health needs of people living with HIV/AIDS who are on ART at three selected hospitals and health centers in Addis Ababa [MPH thesis]. School of Public Health: Addis Ababa University; 2010.

2. Addisse M, Winny K, Azashe W. Developing HIV and AIDS workplace programmes in community service organizations in Ethiopia. 18th International AIDS Conference; 2010; Vienna. Abstract MOPE0656.

3. Aga G. Gap assessment of health facilities laboratory testing and management services in Oromia Regional State. 21st Annual Public Health Conference of the Ethiopian Public Health Association; 2010; Mekele, Ethiopia. Abstract No. 35.

4. Aseresa MM, Tiruneh K, Kellerman S, Kassie Y. HIV positivity and discordance rate among nuclear families of HIV patients enrolled in care at health centers in Ethiopia. 18th International AIDS Conference; 2010; Vienna. Abstract CDE1029.
5. Assefa Y, Schouten E, Chimbwandira F, Hermann $\mathrm{K}$, Van Damme W. Nurse management of HIVinfected patients. Lancet. 2010;376:1053-1054.

6. Assefa Y, Van Damme W, Hermann K. Human resource aspects of antiretroviral treatment delivery models: current practices and recommendations. Curr Opin HIV AIDS. 2010;5:78-82.

7. Assefa Y, Van Damme W, Mariam DH, Kloos H. Toward universal access to HIV counseling and testing and antiretroviral treatment in Ethiopia: looking beyond HIV testing and ART initiation. AIDS Patient Care STDS. 2010;24:521-525.

8. Ayalew EH. Health service intervention: The case of ART for HIV/AIDS patients in Addis Ababa [MA thesis]. Dept of Regional and Local Development Studies: Addis Ababa University; 2010.

9. Barnhart S, Kiefer C, Feleke G, Downer A. Next generation of PEPFAR supports an Ethiopian University and a US University partnership to design a state-of-the-art outpatient care and teaching facility in Gondar, Ethiopia. 138th Annual Conference of the American Public Health Association, ; 2010; Denver, CO, USA. Abstract No. 223244.

10. Becker S, Linsk N, Smith JP. Building capacity to provide coordinated care for orphans to support orphans and vulnerable children: twinning patnerships for training a new cadre of parasocial workers in Africa. 18th International AIDS Conference; 2010; Vienna. Abstract MOPE0875.

11. Bradley E, Curry L, Byam P, Zerihun A, Alpern R, Thompson JW, et al. The Ethiopian millennium rural initiative. 18th International AIDS Conference; 2010; Vienna. Abstract TUPE0872.

12. Brewster-Lee D, Telilla M, Clark A, Belay D. Mobilizing Ethiopian Idirs: Capitalizing on traditional burial societies to serve the living. 18th International AIDS Conference; 2010; Vienna. Abstract MOAD0303.

13. Celletti F, Wright A, Palen J, Frehywot S, Markus A, Greenberg A, et al. Can the deployment of community health workers for the delivery of HIV services represent an effective and sustainable response to health workforce shortages? Results of a multicountry study. AIDS. 2010;24 Suppl 1:S45-S57.

14. Dachew BA. Assessment of acceptance of provider initiated HIV counseling and testing among tuberculosis patients in North Wello Administrative Zone [MN thesis]. Dept of Nursing: Addis Ababa University; 2010.

15. Datiko DG, Lindtjørn B. Cost and costeffectiveness of smear-positive tuberculosis treatment by health extension workers in southern Ethiopia: A community randomized trial. PLoS One. 2010;5:e9158. 
16. Deribew A, Negussu N, Kassahun W, Apers L, Colebunders R. Uptake of provider-initiated counselling and testing among tuberculosis suspects, Ethiopia. Int J Tuberc Lung Dis. 2010;14:1442-1446.

17. Dillnessa E, Enquselassie F. Couples voluntary counselling and testing among VCT clients in Addis Ababa, Ethiopia. Ethiop Med J. 2010;48:95103.

18. Ejeja ZS. Demand for family planning service among young women VCT clients: Need for service integration in Ambo Hospital [MSc thesis]. Aklilu Lemma Institute of Pathobiology: Addis Ababa University; 2010.

19. Fetene NW, Feleke AD. Missed opportunities for earlier HIV testing and diagnosis at the health facilities of Dessie town, North East Ethiopia. BMC Public Health. 2010;10:362.

20. Fried S, Patel D, Ali N. Universal access for women and girls now! A UNDP-led UNAIDS and UNIFEM interagency project. 18th International AIDS Conference; 2010; Vienna. Abstract MOPE1020.

21. Gele AA, Sagbakken M, Abebe F, Bjune GA. Barriers to tuberculosis care: a qualitative study among Somali pastoralists in Ethiopia. BMC Res Notes. 2010;3:86.

22. Geresu SG. Assessment of functionality and competence of health extension workers on family health package in East Shewa Zone, Oromia [MPH thesis]. School of Public Health: Addis Ababa University; 2010.

23. Getachew T, Mekonnen T, Dibaba Y. Family planning use of women living with HIV/AIDS on chronic care at Bishoftu, Ethiopia. 21st Annual Public Health Conference oft the Ethiopian Public Health Asociation; 2010; Mekele, Ethiopia. Abstract No. 9.

24. Ghebreyesus TA, Kazatchkine $M$, Sidibe $M$, Nakatani H. Tuberculosis and HIV: Time for an intensified response. Lancet. 2010;375:17571758.

25. Gillespie D, Bradley H, Karklins S, Kidanu A, Woldegiorgis M. The Voluntary HIV Counseling and Testing Integrated with Contraceptive Services (VICS) Study in Ethiopia: Final Report, February 2010; 2010.

26. Haile Mariam D. Bridging the divide: Linking training to service. Ethiop J Health Dev. 2010;24:87-88.

27. Haile Mariam D. Prospects for self-reliance in the provision of public health services. Ethiop J Health Dev. 2010;24:1-2.

28. Haile Micheal Y, Challi Jira C, Girma B. Health workforce deployment, attrition and density in East Wollega Zone, western Ethiopia. Ethiop J Health Sciences. 2010;20:15-23.

29. Hailegiorgis B, Girma S, Melaku Z, Teshi T, Demeke L, Gebresellasie S, et al. Laboratory malaria diagnostic capacity in health facilities in five administrative zones of Oromia Regional State, Ethiopia. Trop Med Int Health. 2010;15:1449-1457.

30. Hartman AF, Crandall B, Muluken M. An innovative approach to national scale up of comprehensive HIV/AIDS services in Ethiopia. 138th Annual Conference of the American Public Health Association, ; 2010; Denver, CO, USA. Abstract No. 220489.

31. Homolova B, Barbo C. Meeting immediate support needs of Global Fund recipients: exploring potential of existing award mechanisms. 18th International AIDS Conference; 2010; Vienna. Abstract THPE0569.

32. Karim AM, Betemariam W, Alemu H. Effectiveness of health extension program outreach strategies on improving maternal health care utilization in Ethiopia. 21st Annual Public Health Conference of the Ethiopian Public Health Association 2010; Mekele, Ethiopia. Abstract No. 67.

33. Kebede S, Abebe Y, Wolde M, Bekele B, Mantopoulos J, Bradley EH. Educating leaders in hospital management: A new model in SubSaharan Africa. Int J Qual Health Care. 2010;22:39-43.

34. Koblinsky M, Tain F, Gaym A, Karim A, Carnell M, Tesfaye S. Responding to the maternal health care challenge: The Ethiopian Health Extension Program. Ethiop J Health Dev. 2010;24:105-109.

35. Korra A. Knowledge and prevalence of VCT in rural Ethiopia. 18th International AIDS Conference; 2010; Vienna. Abstract CDC0477.

36. Lehmann U. Community health workers and HIV care in low- and middle-income countries: Conceptualizing a diverse and complex phenomenon. 18th International AIDS Conference; 2010; Vienna. Abstract MOPE0880.

37. Linsk NL, Omari L, Tesfahun H, Ezeh C, Uzuegbu C, Becker $S$, et al. Using para-social work to address the needs of vulnerable children in Sub-Saharan Africa. 18th International AIDS Conference; 2010; Vienna. Abstract CDE1233.

38. Loewenberg S. Ethiopia struggles to make its voice heard. Lancet. 2010;376:861-862.

39. Maes K. Examining health care voluntarism in a food- and financially-insecure world. Bull World Health Org. 2010;88:867-869.

40. Maes KC, Shifferaw S, Hadley C, Tesfaye F. Volunteer home-based HIV/AIDS care and food crisis in Addis Ababa, Ethiopia: Sustainability in the face of chronic food insecurity. Health Policy Plan. 2011;26:43-52.

41. Mclaughlin P, Tessama H, Gibney L, Negash H, Endalemaw Y. Effective community health worker approaches in Ethiopian PMTCT. 18th International AIDS Conference; 2010; Vienna. Abstract CDC0546.

Ethiop J Health Dev 2011;25(1) 
42. Mecha MW, Stuer F. Building a palliative care program in Ethiopia: The impact of HIV and AIDS on patients and their families. 18th International AIDS Conference; 2010; Vienna. Abstract MOPE0808.

43. Meche H, Kitaw Y, Teka GE. HRH evolution in Ethiopia: Lessons from the primary health care period (1974-1991). 21st Annual Public Health Conference of the Ethiopia Public Health Association; 2010; Mekele, Ethiopia. Abstract No. 37.

44. Mekonnen MD. The challenges of HIV/AIDS program implementation in Addis Ababa City Administration with particular reference to Lideta Sub City [MA thesis]. Dept of Management Policy: Addis Ababa University; 2010.

45. Melkamu Y, Betre M, Tesfaye S. Utilization of postabortion care services in three regional states of Ethiopia Ethiop J Health Dev. 2004;24:123-129.

46. Mesfin MM, Newell JN, Madeley RJ, Mirzoev TN, Tareke IG, Kifle YT, et al. Cost implications of delays to tuberculosis diagnosis among pulmonary tuberculosis patients in Ethiopia. BMC Public Health. 2010;10:173.

47. Miller RL, Jr., Linsk NL. HIV social work in East Africa. J HIV/AIDS \& Social Services. 2010;9:213219.

48. Ministry of Health. Report on progress towards implementation of the UN Declaration of Commitment on HIV/AIDS 2010. Addis Ababa: Ministry of Health, HIV/AIDS Prevention and Control Office (HAPCO); 2010 March 2010.

49. Ministry of Health. Strategic framework for linkages between HCT and chronic HIV care services in Ethiopia Addis Ababa: Federal Ministry of Health; 2009 August 2009.

50. Ministry of Health. National training package: Provider-initiated HIV testing and counselling. Participants' manual. Addis Ababa: Federal Ministry of Health, HAPCO; 20102010.

51. Ministry of Health. National training package: Provider-initiated HIV testing and counseling. Trainer's manual. Addis Ababa: Federal Ministry of Health, HAPCO; 2010.

52. Ministry of Health. Strategic framework for referral and linkages between HCT and chronic HIV care services in Ethiopia. Addis Ababa. Federal Ministry of Health, August 2009.

53. Ministry of Health. Tuberculosis, leprosy and TB/HIV prevention and control programme: Manual. Addis Ababa: Federal Ministry of Health; 4th edition, 2009.

54. Ministry of Health. ART update as of the end of Yekatit 2002 (March 2010). Addis Ababa: HAPCO; 2010.

55. Morrison JS, Cooke JC. Battling HIV/AIDS in Ethiopia: U.S. approach needs nuance, flexibility.
Washington, D.C.: Center for Strategic International Studies; 2004. p. 35.

56. Nida EK. Mobile based voluntary counseling and testing report collection system [MA thesis]. Dept of Computer Science: Addis Ababa University; 2010.

57. Ololo S, Challi Jirra, Hailemichael Y, Girma B. Indigenous community insurance (Iddirs) as an alternative health care financing in Jimma City, southwest Ethiopia. Ethiop J Health Sci. 2009;19:53-60.

58. OSSREA. The HIV/AIDS Challenge in Africa, an Impact and Response Assessment: The Case of Ethiopia. Addis Ababa: Organization for Social Science Research in Eastern and Southern Africa; 2008.

59. Poer K, Makonnen Y, Hong R. Mobile HIV testing partnerships to reach at risk populations. 37th Annual International Conference on Global Health; 2010; Washington, DC, USA. Abstract No. A4.

60. Ramos JM, Velez M, Reyes F. Analyses of sputum specimens for the diagnosis of pulmonary tuberculosis in a rural hospital in Ethiopia. Int J Tuberc Lung Dis. 2010;14:659-660.

61. Reda AA, Fisseha S, Mengistie B, Vandeweerd JM. Standard precautions: occupational exposure and behavior of health care workers in Ethiopia. PLoS One. 2010;5:e14420.

62. Remme M, Elhassan E, Njoumemi Z, Tushune K, Nwaorgu O, Ekpo U, et al. External monetary incentive policies for community volunteers: findings from a multi-country study. 18th International AIDS Conference; 2010; Vienna. Abstract CDE1223.

63. San Sebastian M. Efficiency of the health extension program in Tigray, Ethiopia: A data envelopmenr analysis. BMC Int Health Hum Rights. 2010;10:16.

64. Sanders R, Mekonnen Y. Equity and access to ART in Ethiopia. 18th International AIDS Conference; 2010; Vienna. Abstract TUPE0981.

65. Shiferaw N, Reason LL, Petracca F, Felek G, Tebekaw Y, Abate T, et al. Holy water sites in Ethiopia: An opportunity for ART scale-up and adherence. 18th International AIDS Confernce; 2010; Vienna. Abstract LBPE 36.

66. Sinkineh L, McCrossan G. Eliminating harmful traditional practices in Ethiopia: Insights from Ethiopia. 18th International AIDS Conference; 2010; Vienna. Abstract MOPE0800.

67. Sippel S, Hastings MB, Allana D. U.S. policy impact on progress and barriers to young people's sexual and reproductive health and rights (SRHR) in Ethiopia. 18th International AIDS Conference; 2010; Vienna. Abstract CDF1355.

68. Tamiru M, J. H. Hospital bed occupancy and HIV/AIDS in three major public hospitals of Addis

Ethiop J Health Dev 2011;25(1) 
Ababa, Ethiopia. Int J Biomed Sci. 2010;6:195201.

69. Tesfaye D, Abdallah $\mathrm{H}$, Assefa $\mathrm{Y}$, Tassew F, Shiferaw F, Mohammed A. Meeting universal access challenges: commodity security through systems and coordination. 18th International AIDS Conference; 2010; Vienna. Abstract CDE1047.

70. Teshome DA. Perceived sources of work related stress and coping strategies among VCT counselors in Addis Ababa [MA thesis]. Dept of Social Psychology: Addis Ababa University; 2010.

71. Tessema SL. Determinants of knowledge and service availability and utilization of sexual and reproductive health: A comparitive study of preparatory students [MA thesis]. Dept of Gender Studies: Addis Ababa University; 2010.

72. Vassall A, Seme A, Compernolle P, Meheus F. Patient costs of accessing collaborative tuberculosis and human immunodeficiency virus interventions in Ethiopia. Int J Tuberc Lung Dis. 2010;14:604-610.

73. Wube M, Horne CJ, Stuer F. Building a palliative care program in Ethiopia: The impact on HIV and AIDS patients and their families. J Pain Symptom Manage. 2010;40:6-8.

74. Zeru DG. Comparative study of burnout and coping strategies by councelors in face to face and online counseling services in Addis Ababa [MA thesis]. Dept of Counseling Psychology: Addis Ababa University; 2010.

75. Zewde IF. A study on the feasibility of health insurance schemes for community based groups [MA thesis]. Dept of Journalism and Communication: Addis Ababa University; 2010.

\section{Section 6. Prevention Research}

This section includes reports on research and programmatic activities that are aimed at provision of prevention services targeted against HIV/AIDS and related opportunistic infections. Included in this section are studies on information and behavioral change communication, provision of voluntary testing and counseling and mother-to-child transmission prevention services, community mobilization, and other efforts against HIV/AIDS.

1. Abebe H. Consumption of vitamin A rich foods and dark adaptation threshold of pregnant women at Damot Sore District, Wolayta, southern Ethiopia. 21st Annual Public Health Conference of the Ethiopian Public Health Association; 2010; Mekele, Ethiopia. Abstract No. 51.

2. Addis G, Baskaran R, Raju M, Ushadevi A, Asfaw Z, Woldu Z, et al. Nutritional and health benefits of carotenoides and their intake optimization from green vegetables. 21st Annual Public Health Conference oft he Ehiopian Public Health
Association; 2010; Mekele, Ethiopia. Abstract No. 50.

3. Adeba E. Acceptability of provider initiated counseling and testing among tuberculosis and non-tuberculosis patients in Shashemene Town, West Arsi Zone, Oromia Region, Ethiopia [MPH thesis]. School of Public Health: Addis Ababa University; 2010.

4. Ahmed YA, Robie B, Hamuse SD, Damena TK, Eticha SW. Addressing PMTC gaps through a systematic process improvement (PI) approach. 18th International AIDS Conference; 2010; Vienna. Abstract WEPDE102.

5. Alemayehu H. Condom and kerosene reaching housemaids with HIV-prevention. 18th International AIDS Conference; 2010; Vienna. Abstract WEPE0387.

6. Asefa A. Assessment of overall quality of prevention of mother-to-child transmission (PMTCT) of HIV service in Adama, Ethiopia. 18th International AIDS Conference; 2010; Vienna. Abstract no. CDC0409.

7. Ashengo T, Curran K, Mulwanda J, Chinkoyo E. Surgical time and number of procedures conducted during training varies by type of adult MC procedure. 18th International AIDS Conference; 2010; Vienna. Abstract MOPE0344.

8. Aynalum EF. The effect of integrating HIV related health education with adult literacy programs in Bahir Dar, Ethiopia. 18th International AIDS Conference; 2010; Vienna. Abstract CDD0900.

9. Berhanu E, Melles M, Imram L. Ethiopian Youth Speaks Out: Mobilization. videography, budget tracking and advocacy for sexual and reproductive health and rights for a comprehensive approach to HIV prevention. 18th International AIDS Conference; 2010; Vienna. Abstract MOPE0986.

10. Bery R, Rosenbaum J. How to integrate water, sanitation and hygiene into HIV programmes. Geneva: World Health Organization; 2010.

11. Beshir JA. Comparison of factors influencing utilization of modern contraceptive methods among rural and urban women currently using family planning service in South Wollo Zone, Amhara National Regional State [MPH thesis]. School of Public Health: Addis Ababa University; 2010.

12. Birru AD. Determinants of PIHCT acceptance among patients visiting health care facilities in Sheka Zone, southwest Ethiopia: A comparitive study [MPH thesis]. School of Public Health: Addis Ababa University; 2010.

13. Biru M, Eek F. Prophylactic treatment uptake and compliance with recommended follow-up among HIV exposed infants: A retrospective study in Addis Ababa, Ethiopia. 21st Annual Public Health Conference of the Ethiopian Public Health

Ethiop J Health Dev 2011;25(1) 
Association; 2010; Mekele, Ethiopia. Abstract No. 6.

14. Bogale G, Boer H, Seydel E. Effectiveness of oral HIV/AIDS prevention messages for illiterate rural women in the Amhara region, Ethiopia. 18th International AIDS Conference; 2010; Vienna. Abstract MOPE0540.

15. Bogale GW, Boer H, Seydel ER. Condom use among low-literate, rural females in Ethiopia: The role of vulnerability to HIV infection, condom attitude, and self-efficacy. AIDS Care. 2010;22:851-857.

16. Bogale GW, Boer H, Seydel ER. Reaching the hearts and minds of illiterate women in the Amhara highland of Ethiopia: Development and pre-testing of oral HIV/AIDS prevention messages. Sahara J Social Aspects of HIV-AIDS. 2010;7:2-9.

17. Bradley H, Tsui A, Kidanu A, Gillespie D. Client characteristics and HIV risk associated with repeat HIV testing among women in Ethiopia. AIDS Behav. 2010.

18. Bradley HM. Psychosocial motivations for repeat HIV testing among Ethiopian women. Dissertation Abstracts International: Section B: The Sciences and Engineering Vol71(1-B),2010, pp 254. 2010;71: p. 254.

19. Brewster-Lee D, Telilla M, Clark A, Belay D. The Faithful House: effectiveness in challenging gender norms for the reduction of multiple and concurrent partnerships. 18th International AIDS Conference; 2010; Vienna. Abstract WEPE0437.

20. Bukassa KD. Condom social marketing and HIV/AIDS prevention: The case of commercial sex workers in some selected areas of Addis Ababa and cities around Addis Ababa [MA thesis]. Dept of Marketing Management Education: Addis Ababa University; 2010.

21. Burussie A. Assessment of the determinant factor of PMTCT. 21st Annual Public Health Conference of the Ethiopian Public Health Association; 2010; Mekele, Ethiopia. Abstract No. 1.

22. CDC. Global reproductive health: Modeling and reinforcement to combat HIV/AIDS (MARCH). Atlanta: Centers for Disease Control and Prevention, Division of Reproductive Health, National Center for Chronic Disease Prevention and Health Promotion; 2008 July 29.

23. Chebo MM. Determinants and adherence to PMTCT among mothers attending ANC in SNNPR hospitals [MN thesis]. Dept of Nursing: Addis Ababa University; 2010.

24. Dagne HG. Ethiopia: Social dynamics of abandonment of harmful practices. Experiences in four locations Annunziata, Italy: UNICEF, Innocenti Research Center; 2010 May 2010. Report No.: IMP-2009-07.
25. Dakito A. Determinants of provider initiated HIV counseling and testing among patients visiting health care facilities in Sheka Zone, southwest Ethiopia [MPH thesis]. School of Public Health: Addis Ababa University; 2010.

26. Desta EE. Participatory research based stigma reduction intervention among nomadic community in Afar Region, Ethiopia. 18th International AIDS Conference; 2010; Vienna. Abstract TUPE0646.

27. Doyle AM, Napierala Mavezenge S, Ross DA. HIV prevention in young people in Sub-Saharan Africa: A systematic review and update of the evidence. 18th International AIDS Conference; 2010; Vienna. Abstract WEAC0201.

28. Erulkar AS, Ferede A, Ambelu W, Girma W, Amdemichael HA, Gebre Medhin B. Ethiopia Young Adult Survey: A Study in Seven Regions; 2010.

29. Ferede TN. Assessment of the contraceptive prevalence and determinant factors among currently married women in reproductive age (15-49) group in Derashe Special Woreda, SNNPR, Ethiopia [MPH thesis]. School of Public Health: Addis Ababa University; 2010.

30. Gari T, Habte D, Markos E. HIV positive status disclosure to sexual partner among women attending ART clinic at Hawassa University Referral Hospital, SNNPR, Ethiopia. Ethiop J Health Dev. 2010;24:9-14.

31. Gebre Yesus D, Fantahun M. Assessing communication on sexual and reproductive health issues among high school students with their parents, Bullen Wereda, Benishangul Gumuz Region, Northwest Ethiopia. Ethiop J Health Dev. 2010;24:89-95.

32. Gebreegziabher D, Women. Knowledge attitudes and practices towards prevention of mother to child transmission of HIV among antenatal care mothers in Gedio, South Ethiopia. 18th International AIDS Conference; 2010; Vienna. Abstract CDC0267.

33. Gebremedhin S. Assessment of the protective effect of male circumcision from HIV infection and sexually transmitted diseases: evidence from 18 demographic and health surveys in subSaharan Africa. Afr J Reprod Health. 2010;14:105113.

34. Gebreselassie S. The protective effect of male circumcision from HIV infection and sexually transmitted diseases: evidence from 18 demographic and health surveys in Sub-Saharan Africa. 18th International AIDS Conference; 2010; Vienna. Abstract MOPE0328.

35. Gebreselassie SF. Assessment of voluntary counseling among preparatory students in Awassa town [MPH thesis]. School of Public Health: Addis Ababa University; 2010.

Ethiop J Health Dev 2011;25(1) 
36. Gerbi EA. Assessment of willingness to accept provider intitiated HIV counseling and testing among tuberculosis and non-tuberculosis is Shashemene Town, West Arsi Zone [MPH thesis]. School of Public Health: Addis Ababa University; 2010.

37. Hecker G, Mehta M, Mohamed A, Mulu B, Kidanu A, Pulerwitz J. Reframing vertical transmission in Ethiopia: The prevention of parent-to-child transmission of HIV. 18th International AIDS Conference; 2010; Vienna. Abstract TUPE0779.

38. Jada TS. Determinants of willingness to utilize prevention of mother to child transmission of HIV among pregnant women in Addis Ababa [MA thesis]. Dept of Population Studies: Addis Ababa University; 2010.

39. Kahsay H. Use of indigenous communication approaches for HIV/AIDS prevention: The case of Erob Woreda, northeastern Tigray [MA thesis]. Dept of Journalism and Communication: Addis Ababa University; 2010.

40. Kirby D. What does good quality sexuality education for HIV prevention mean? Developing a minimum package for schools, teachers and health educators. 18th International AIDS Conference; 2010; Vienna. Abstract MOPDX101.

41. Levack A, Castillo TP, Mehta M, Verani F, Pulerwitz J, Hecker G, et al. Addressing harmful gender norms to improve health: Strengthening local capacity in male engagement \& HIV prevention. 138th Annual Conference of the American Public Health Association, ; 2010; Denver, CO, USA. Abstract No. 222195.

42. Mansfeld C-S, Teshome Y. On the gender differentiated use of mobile VCT services in Ethiopia. 18th International AIDS Conference; 2010; Vienna. Abstract CDD0989.

43. McCrossan G, Sinkineh L. Using a social capita behaviour model to reduce stigma and increase HIV testing: Insights from Concern Worldwide Ethiopia. 18th International AIDS Conference; 2010; Vienna. Abstract MOPE0636.

44. McKay B, Guth RA. Global AIDS fight shifts toward prevention. Wallstreet Journal. 2010 July 17;Sect. A3.

45. Mekonnen A, Erku W. Knowledge and attitude towards monther-to-child transmisison of HIV and its prevention methods among mothers attending the antenatal care clinics at ten selected health centers in Addis Ababa. 21st Annual Public Health Conference of the Ethiopian Public Health Association; 2010; Mekele, Ethiopia. Abstract No. 3.

46. Melaka TL. Perceptions and practices of contraceptives in Bahir Dar: A gender perspective [MA thesis]. Dept of Social Psychology: Addis Ababa University; 2010.
47. Melesse DA. Assessment of sexual risk perception and the determinants of protective behavior of STIs/HIV/AIDS among female college students in Debre Markos Town, Amhara Region [MPH thesis]. School of Public Health: Addis Ababa University; 2010.

48. Melles M. Success in youth-led advocacy: Process in supporting comprehensive, positive approaches to HIV prevention for youth in Ethiopia, Jamaica, Nigeria, and the United States. 18th International AIDS Conference; 2010; Vienna. Abstract MOPE0983.

49. Ministry of Health. Health care waste management national guidelines. Addis Ababa; November 2008.

50. Ministry of Health. Putting Prevention First: National HIV/AIDS Summit. Addis Ababa: Ministry of Health, HAPCO; 2010 April 6-8, 2009.

51. Mirkuzie AH, Hinderaker SG, Morkve 0. Promising outcomes of a national programme for the prevention of mother-to-child HIV transmission in Addis Ababa: A retrospective study. BMC Health Serv Res. 2010;10:267.

52. Mitke YB. Bloody traditional procedures performed during infancy in the oropharyngeal area among HIV+ children: implication from the perspective of mother-to-child transmission of HIV. AIDS Behav. 2010;14:1428-1436.

53. Molla M, Emmelin M, Berhane Y, Lindtjørn B. Readiness of youth in rural Ethiopia to seek health services for sexually transmitted diseases. Afr J AIDS Res. 2010;8:135-146.

54. Morrone A, Uccella I, Rosso A, Di Palma R, Fazioli C, Agnoletto V, et al. AIDS and mobility project: A new peer education method on HIV prevention for migrant and mobile populations. 18th International AIDS Conference; 2010; Vienna. Abstract TUPE1052.

55. Muletta TE. Rights based approach to HIV prevention and economic empowerment among sex workers in Addis Ababa, Ethiopia. 18th International AIDS Conference; 2010; Vienna. Abstract WEPE0742.

56. Nuro BT. Contraceptive social marketing [MA thesis]. Dept of Business Administration: Addis Ababa University; 2010.

57. Oli Gebru S. Role of girls in school based HIV/AIDS response. 18th International AIDS Conference; 2010; Vienna. Abstract CDD0928.

58. Oloo J, Ababeye B. Role of religious leaders in enhancing sustainability of OVC care and support programs. 18th International AIDS Conference; 2010; Vienna. Abstract CDE1186.

59. Omer S, Haidar J. Applicability of the theory of planned behavior in predicting intended use of voluntary HIV Counseling and Testing services among teachers of Harari Region, Ethiopia. Ethiop J Health Dev. 2010;24:96-102. 
60. Osman SK. Attitude and practices on HIV prevention among Addis Ababa University students [MA thesis]. Dept of Population Studies: Addis Ababa University; 2010.

61. Pulerwitz J, Martin S, Mehta M, Castillo I, Kidanu A, Verani F. Promoting gender equity for HIV and violence prevention: the male norms initiative in Ethiopia 18th International AIDS Conference; 2010; Vienna. Abstract TUPE0675.

62. Rowe A-K, Edwards O, Nelson J. Jamaican youth speak out: mobilizing youth and advocating for change to address HIV in the context of sexual and reproductive health and right. 18th International AIDS Conference; 2010; Vienna. Abstract TUPE0882.

63. Shewakena Z. Seeking alternative income earning mechanism for HBC graduated PLWHs' to ensure food security at their household level in Kirkos area, Addis Ababa City. 18th International AIDS Conference; 2010; Vienna. Abstract CDE1320.

64. Simpson-Hebert M. "We stop AIDS" prevention education curriculum brings behavior change in East Africa. 18th International AIDS Conference; 2010; Vienna. Abstract MOPE0610.

65. Tadele G. "Boundaries of sexual safety": Men who have sex with men (MSM) and HIV/AIDS in Addis Ababa. J HIV/AIDS \& Social Services. 2010;9:261280.

66. Tekletsadik M. Enhancement of women and girls reproductive rights in Ethiopia. 18th International AIDS Conference; 2010; Vienna. Abstract MOPE0497.

67. Tesfaye S. A national scoping exercise and strategic recommendations for working with individuals, families and communities to improve maternal and neonatal health in Ethiopia. Ethiop J Health Dev. 2010;24:89-91.

68. Tiku TB. The impact of social marketing on contraceptive utilization [MA thesis]. Dept of Marketing Management Education: Addis Ababa University; 2010.

69. Tiyou A, Belachew PT, Alemseged DF, Biadgilign S. Food insecurity and coping strategies under clinical care setting among HIV infected adult persons in Southwest Ethiopia. 18th International AIDS Conference; 2010; Vienna. Abstract CDF1353.

70. UNAIDS. Global Report: UNAIDS Report on the Global AIDS Epidemic 2010. Geneva: World Health Organization; 2010.

71. UNDP. Upscaling Community Conversations: Unleashing Capacities of Communities for the HIV/AIDS Response. New York: UNDP; 2004.

72. Viswanathan R, Ekpini RE, Chatterjee A, Burke D, Johnson K, Luo C. Married women don't use condoms: An analysis of population-based data to understand PMTCT knowledge and practice. 18th
International AIDS Conference; 2010; Vienna. Abstract MOPE0283.

\section{Section 7. Treatment, Care, Clinical Research}

This section includes studies on the characteristics and clinical course of HIV infection and opportunistic infections, treatment to AIDS and opportunistic infections, effects and outcomes associated with treatment, clinical and non-clinical care and supportive services provided to people living with HIV/AIDS.

1. Abera B, Walle F, Tewabe T, Alem A, Yessin M. ART-naive HIV patients at Felege-Hiwot Referral Hospital, northwest Ethiopia. Ethiop J Health Dev. 2010;24:3-14.

2. Adewo DS. Clinical presentation and treatment of TB among HIV positive TB patients on short course DOTS in Hawassa Referral Hospital: A retrospective cohort study [MPH thesis]. School of Public Health: Addis Ababa University; 2010.

3. Adlo AM. Comparison of antiretroviral treatment outcomes for a general hospital versus that of health centers: A retrospective cohort study [MPH thesis]. School of Public Health: Addis Ababa University; 2010.

4. Alayneh H, Crandall B, Birru M, Melese M, Hartman AF. Improved ART adherence through case management in Ethiopia. 18th International AIDS Conference; 2010; Vienna. Abstract MOPE0803.

5. Alemu AW, Sebastian MS. Determinants of survival in adult HIV patients on antiretroviral therapy in Oromiyaa, Ethiopia. Glob Health Action. 2010;3.

6. Angessa R. Predictors of mortality and health related quality of life in patients receiving ART, Adama [MPH thesis]. School of Public Health: Addis Ababa University; 2010.

7. Aragie K, Amare AS, Kendall C, Jerene D, Azmera $\mathrm{T}$. Incidence of tuberculosis and early mortality in HIV infected patients initiating antiretroviral therapy in Zewditu Memorial Hospital, Ethiopia. 18th International AIDS Conference; 2010; Vienna. Abstract MOPE0141.

8. Aycheh MW. Assessment of the impact of HIV/AIDS testing on the treatment seeking behavior of tuberculosis patients in Addis Ababa [MSc thesis]. Aklilu Lemma Institute of Pathobiology: Addis Ababa University; 2010.

9. Balcha T. Outcomes of antiretroviral treatment: A comparison between hospitals and health centers in Ethiopia.138th Annual Conference of the American Public Health Association; 2010; Denver, CO, USA. Abstract No. 214055.

10. Balcha TT, Jeppsson A. Outcomes of antiretroviral treatment: a comparison between hospitals and health centers in Ethiopia. J Int Assoc Physicians AIDS Care (Chic). 2010;9:318-324. 
11. Beka TD. The experience of street children in the rehabilitation program of Addis Ababa: The case of Retrack Ethiopia street children project [MA thesis]. School of Social Work: Addis Ababa University; 2010.

12. Berhanu Z. Holy water as an intervention for HIV/AIDS in Ethiopia. J HIV/AIDS \& Social Services. 2010;9:240-260.

13. Berhe FH. Assessment of parental influence on pediatrics highly active antiretroviral therapy (HAART) adherence in Addis Ababa [MPH thesis]. School of Public Health: Addis Ababa University; 2010.

14. Beyene AB. Predictors of mortality and quality of life in HIV/AIDS patients receiving ART in Adama Hospital, Oromia Region [MPH thesis]. School of Public Health: Addis Ababa University; 2010.

15. Birenboim R. Dental reflections from Ethiopia. Alpha Omegan. 2010;103:119-122.

16. Datiko DG, Lindtjørn B. Mortality in successfully treated tuberculosis patients in southern Ethiopia: Retrospective follow-up study. Int J Tuberc Lung Dis. 2010;14:866-871.

17. Dessie Y, Davey G. Risky sexual practice and related factors among ART at tenders in Addis Ababa public health hospitals. 21st Annual Public Health Conference of the Ethiopian Public Health Association; 2010; Mekele, Ethiopia. Abstract No. 10.

18. Desta H. Sustaining OVC care and support by empowering OVC guardians and the community through a faith-based initiative. 18th International AIDS Conference; 2010; Vienna. Abstract WEPE0802.

19. Ergete D. Clinical and immunologic response of HIV patients on different ART regimens at Gondar University Hospital (GUH). Int J Infect Dis. 2010;14:e241-e242.

20. Gaga T. The impact of palliative care on ART adherence at Dilla, Hawassa and Soddo Medan ACTS project sites, SNNPR, Ethiopia. 18th International AIDS Conference; 2010; Vienna. Abstract CDE1096.

21. Gebremariam MK, Bjune GA, Frich JC. Barriers and facilitators of adherence to TB treatment in patients on concomitant TB and HIV treatment: A qualitative study. BMC Public Health. 2010;10:651.

22. Gelan Z. Adherence to antiretroviral therapy among adult people living with HIV/AIDS on highly active antiretroviral therapy at selected health centers in Wolaita and Gamo Gofa Zones, south Ethiopia, 2010 [MPH thesis]. School of Public Health: Addis Ababa University; 2010.

23. Gemeda AT. Determinants of defaulting from antiretroviral programmes in Harar, eastern Ethiopia [MPH thesis]. School of Public Health: Addis Ababa University; 2010.
24. Getachew M. Challenges related to antiretroviral therapy adherence among children living with HIV and AIDS: The case of primary care givers experiences coming to Zewditu Memorial Hospital ART Center, Addis Ababa [MA thesis]. School of Social Work Addis Ababa University; 2010.

25. Getahun B. Treatment outcomes of TB patients under DOTS in Addis Ababa, Ethiopia [MSc thesis]. Aklilu Lemma Institute of Pathobiology: Addis Ababa University; 2010.

26. Getahun B, Ameni G, Biadgilign S, Medhin G. Survival rate and risk factors for mortality among a cohort of tuberculosis patient treated under DOTS programme in Addis Ababa, Ethiopia. 21st Annual Public Health Conference of the Ethiopian Public Health Association; 2010; Mekele, Ethiopia. Abstract No. 47.

27. Gibney L, Laughlin PM, Tessema H, Hagos S. Assessing the impact of Ethiopian mother support groups (MSG) on ARV prophylaxis uptake and facility-based deliveries. 37th Annual International Conference on Global Health; 2010; Washington, DC, USA. Abstract No. F6.

28. Giday A, Shiferaw W. Factors affecting adherence of antiretroviral treatment among AIDS patients in an Ethiopian tertiary university teaching hospital. Ethiop Med J. 2010;48:187-194.

29. Girma A, H/Mariam D, Deribe K. Quality of tuberculosis care in six health facilities of Afar Region, Ethiopia. Ethiop Med J. 2010;48:195-202.

30. Hailu W, Amza G, Anderson C, Kamote E, Herman M, Hammink ME, et al. Applying the "Science of Improvement" to programmes for orphans and vulnerable children. 18th International AIDS Conference; 2010; Vienna. Abstract TUPE0888.

31. Hailu W, Weldegebreal T, Hurissa Z, Tafes H, Omollo R, Yifru S, et al. Safety and effectiveness of meglumine antimoniate in the treatment of Ethiopian visceral leishmaniasis patients with and without HIV co-infection. Trans R Soc Trop Med Hyg. 2010;104:706-712.

32. Hartman AF, Crandall B, Muluken M, Ayalneh $\mathrm{H}$, Birru M. ART adherence through case managment in Ethiopia 138th Annual Conference of the American Public Health Association, ; 2010; Denver, CO, USA. Abstract No. 220651.

33. Hurissa Z, Gebre-Silassie S, Hailu W, Tefera T, Lalloo DG, Cuevas LE, et al. Clinical characteristics and treatment outcome of patients with visceral leishmaniasis and HIV co-infection in northwest Ethiopia. Trop Med Int Health. 2010;15:848-855.

34. Huruy K, Kassu A, Mulu A, Wondie Y. Immune restoration disease and changes in CD4+ T-cell count in HIV- infected patients during highly active antiretroviral therapy at Zewditu Memorial Hospital, Addis Ababa, Ethiopia. AIDS Res Ther. 2010;7:46.

Ethiop J Health Dev 2011;25(1) 
35. Jemal S. Assessment of TB screening and referral linkage among HIV patients attending ART clinic of Butajira, SNNPR, and Ethiopia. 21st Annual Public Health Conference of the Ethiopian Public Health Association; 2010; Mekele, Ethiopia. Abstract No. 12.

36. Jerene D, Mullisa Z, Eltom A, Lindtjorn B. Trends in disease stage at presentation to care and preART outcomes: Findings from a six-year HIV cohort data from southern Ethiopia. 18th International AIDS Conference; 2010; Vienna. Abstract TUAB0203.

37. Kebebew T, Telake DS, Tensori B, Araya T, Reniers G. Providing care to termnially ill people in Addis Ababa, Ethiopia. 18th International AIDS Conference; 2010; Vienna. Abstract THPE0763.

38. Kinfemes TG. Fertility and assessment of people living with HIV/AIDS who are on ART at Zewditu Hospital [MPH thesis]. School of Public Health: Addis Ababa University; 2010.

39. Lewite EM. Assessment of prevalence, determinants and associated factors of mental disorder in people living with HIV/AIDS who are on ART [MPH thesis]. School of Public Health: Addis Ababa University; 2010.

40. Mekonnen Y, Habtemariam B, Desta K, Fentaw S, Asefa M, Assamene $\mathrm{N}$, et al. Prevalence of potential fungal pathogens from smear-negative pulmonary tuberculosis suspected patients visiting St Peter TB Specialized Hospital, Addis Ababa, Ethiopia. 21st Annual Public Health Conference of the Ethiopian Public Health Association; 2010; Mekele, Ethiopia. Abstract No. 43.

41. Mengistei AH. The experience of orphanage, case study of Akaki L'Esperance Children Aid Organization (ALCAO) orphans [MA thesis]. School of Social Work: Addis Ababa University; 2010.

42. Miiro GM, Kaleebu P, Grosskurth H. The East African Consortium for Clinical Research (EACCR): A network to strengthen clinical research and practice on major infections in the region. 18th International AIDS Conference; 2010; Vienna. Abstract TUPE0863.

43. Ministry of Health. National guidelines for the management of sexually transmitted infections using the syndromic approach. Addis Ababa: Ministry of Health, HIV/AIDS Prevention and Control Office; March 2006.

44. Morrone A, Dassoni F, Pajno MC, Marrone R, Calcaterra R, Franco G, et al. Ulcers of the face and neck in a woman with pulmonary tuberculosis: presentation of a clinical case. Rural Remote Health. 2010;10:1485.

45. Morrone A, Rosso A, Dassoni F, Uccella I, Barnabas GA. HIV-associated skin conditions in the population of the Italian Dermatological
Centre of Mekelle, Tigray, Ethiopia. 18th International AIDS Conference; 2010; Vienna. Abstract THPE0227.

46. Moshago AE. Adherence to antiretroviral therapy among patients at Dilla Hospital, Southern Ethiopia. 18th International AIDS Conference; 2010; Vienna. Abstract CDB0204.

47. Mulissa Z, Jerene D, Lindtjørn B. Patients present earlier and survival has improved, but pre-ART attrition is high in a six-year HIV cohort data from Ethiopia. PLoS One. 2010;5:e13268.

48. Munoz-Sellart M, Cuevas LE, Tumato M, Merid Y, Yassin MA. Factors associated with poor tuberculosis treatment outcome in the Southern Region of Ethiopia. Int J Tuberc Lung Dis. 2010;14:973-979.

49. Russell N, Green C, Yimam M. Urban Gardens Program (UGP) for AIDS affected women and OVC links Ethiopia's health and agricultural strategies for a cohesive approach to urban gardening and empowers local project champions in shift toward sustainability. 18th International AIDS Conference; 2010; Vienna. Abstract THP0875.

50. Sastry J, The Six Week Extended Dose Nevirapine (SWEN) Study Team. Extended-dose nevirapine to 6 weeks of age for infants in Ethiopia, India, and Uganda: A randomized trial for prevention of HIV transmission through breastfeeding. 17th Conference on Retroviruses and Opportunistic Infections 2010; San Francisco, CA, USA. Abstract No. 43.

51. Seboxa T, Alemu S, Assefa A, Asefa A, Diro E. Cryptococcal meningitis in patients with acquired immunodeficiency syndrom in pre HAART era at Gondar College of Medical Sciences Hospital, North-West Ethiopia. Ethiop Med J. 2010;48:237241.

52. Shaweno D. Clinical presentation and treatment outcome of TB among HIV positive patients on short course DOTs in Hawassa Health Center: A retrospecitve cohort study [MPH thesis]. School of Public Health: Addis Ababa University; 2010.

53. Shaweno D, Worku A. Clinical presentation and treatment outcome of tuberculosis among HIV positive TB pateints on DOTs in Hawassa Health Center: A retrospective study. 21st Annual Public Health Conference of the Ehiopian Public Health Association; 2010; Mekele, Ethiopia. Abstract No. 44.

54. Shurie JS, Deribew A. Assessment of the prevalence of distal symmetrical polyneuropathy and its risk factors among HAART-treated and untreated HIV infected individuals. Ethiop Med J. 2010;48:85-93.

55. Solomon T, Haileamlak A, Girma B. Effect of access to antiretroviral therapy on stigma, Jimma University Hospital, southwest Ethiopia. Ethiop J Health Sci. 2008;18:25-32. 
56. Talman A, Musvosvi H, Pasternak S, Abebe Y, Mola SG. Assessing the extent and reasons for loss to follow-up in a pediatric HIV clinic in northern Ethiopia 138th Annual Conference of the American Public Health Association, ; 2010; Denver, CO, USA. Abstract No. 223058.

57. Taye B, Shiferaw S, Enquselassie F. The impact of malnutrition in survival of HIV infected children after initiation of antiretroviral treatment (ART). Ethiop Med J. 2010;48:1-10.

58. Tebeje B, Hailu C. Assessment of HIV postexposure prophylaxis use among health workers of governmental health institutions in Jimma Zone, Oromiya Region, southwest Ethiopia. Ethiop J Health Sci. 2010;20:55-64.

59. Tema ZG. Adherence to ART among adult PLWHA on HAART at primary health care facilities in SNNPR, Ethiopia. [MPH thesis]. School of Public Health: Addis Ababa University; 2010.

60. Tessema B, Biadglegne F, Mulu A, Getachew A, Emmrich F, Sack U. Magnitude and determinants of nonadherence and nonreadiness to highly active antiretroviral therapy among people living with HIV/AIDS in Northwest Ethiopia: A crosssectional study. AIDS Res Ther. 2010;7:2.

61. Tiyou A, Belachew T, Alemseged F, Biadgilign S. Predictors of adherence to antiretroviral therapy among people living with HIV/AIDS in resourcelimited settings of southwest Ethiopia. AIDS Res Ther. 2010;7:39.

62. Weiss J, Yeboah $\mathrm{K}$, Damtew W. Improving nutrition of HIV+ mothers and children through integrated HIV and food and nutrition security programming. 18th International AIDS Conference; 2010; Vienna. Abstract THPE0775.

63. Weldeab TE. Assessment of knowledge, attitude, practice about ART and its factors among women living with HIV/AIDS under ART follow-up in health centers of Addis Ababa [MSc thesis]. School of Public Health: Addis Ababa University; 2010.

64. Yitbarek A. Prevalence of ARV related adverse drug reactions among children taking HAART at Tikur Anbessa Specialized Hospital [MA thesis]. Dept of Statistics: Addis Ababa University; 2010.

65. Zijenah L, Tshabalala M, Manase J, Rusakaniko S, Kadzirange G, Kassaye S, et al. Lack of evidence of primary drug resistance in women attending antenatal clinics in Chitungwiza, Zimbabwe. 18th International AIDS Conference; 2010; Vienna. Abstract THPE0356.

Section 8. Health Informatics, Monitoring, and Evaluation Research

This section includes studies on the characteristics and clinical course of HIV infection and opportunistic infections, treatment to AIDS and opportunistic infections, effects and outcomes associated with treatment, clinical and non-clinical care and supportive services provided to people living with HIV/AIDS.

1. Abate B, Enquselassie F. Information use in patients' referral system at Tikur Anbessa Specialized Hospital, Addis Ababa, Ethiopia. Ethiop Med J. 2010;48:123-135.

2. Accorsi S, Bilal NK, Farese P, Racalbuto V. Countdown to 2015: Comparing progress towards the achievement of the health Millennium Development Goals in Ethiopia and other sub-Saharan African countries. Trans R Soc Trop Med Hyg. 2010;104:336-342.

3. Amenu TA, Anteneh G. Community scorecards for improving accountability in the delivery of HIV/AIDS services. 18th International AIDS Conference; 2010; Vienna. Abstract TUPE0975.

4. Aragie K, Moreira dos Santos E, Carl K, Jerene D, Deribew A, Azmera T. Implementations evaluation of linkages between TB and HIV programmes at Zewditu Memorial Hospital, Ethiopia. 18th International AIDS Conference; 2010; Vienna. Abstract THPE0455.

5. Belete AAA. Assessment of counseling services in Addis Ababa mobile voluntary counseling and testing center [MA thesis]. Dept of Counseling Psychology: Addis Ababa University; 2010.

6. Bradley H, Hindin M, Tsu A, Kidanu A, Gillespie D, Karlins S. Self-assessments of HIV risk among Ethiopian women testing for HIV: A qualitative study. 18th International AIDS Conference; 2010; Vienna. Abstract TUPE0636.

7. Bradley H, Tsui A, Kidanu A, Gillespie D. Developing scales to measure perceived HIV risk and vulnerability among Ethiopian women testing for HIV. 18th International AIDS Conference; 2010; Vienna. Abstract CDD0968.

8. Chalker JC, Andualem T, Gitau LN, Ntaganira J, Obua $\mathrm{C}$, Tadeg $\mathrm{H}$, et al. Measuring adherence to antiretroviral treatment in resource-poor settings: the feasibility of collecting routine data for key indicators. BMC Health Serv Res. 2010;10:43.

9. Deribe K, Woldemichael K, Njau BJ, Yakob B, Biadgilign S, Amberbir A. Gender differences regarding barriers and motivators of HIV status disclosure among HIV-positive service users. Sahara J Social Aspects of Hiv-Aids. 2010;7:30-39.

10. Fetene GT, Dimitriadis G. Globalization, public policy, and 'knowledge gap': Ethiopian youth and the HIV/AIDS pandemic. J Education Policy. 2010;25:425-441.

11. FHAPCO. Report on progress towards implemenation of the UN Declaration of Commitment on HIV/AIDS. Addis Ababa: Federal HIV/AIDS Prevention and Control Office March 2010.

12. Fideno BB. Assessment of the status of HIV/AIDS mainstreaming at the government sectors in

Ethiop J Health Dev 2011;25(1) 
Addis Ababa and factors affecting the implementation [MPH thesis]. School of Public Health: Addis Ababa University; 2010.

13. Ghebreyesus TA. Achieving the health MDGs: Country ownership in four steps. Lancet. 2010;376:1127-1128.

14. Gruskin S, Ferguson L, Peersman G, Andreeva V, Fontaine C, Pascom AR, et al. Monitoring the monitoring: Maximizing the value at nationallevel of international monitoring processes. 18th International AIDS Conference; 2010; Vienna. Abstract TUPE0954.

15. Habte D. Assessment of the distribution of at-risk populations and HIV/AIDS referral services in Ethiopia: Baseline assessment for mobile HIV counseling and testing program in Amhara Region. Bethesda, MD: Abt Associates; 2008 July 2008.

16. Hotchkiss D, Banteyerga H, Kidanu A, Tharaney M, Callahan K. How has the scale-up of HIV/AIDS services influenced other priority health care services? Evidence from panel of primary health care facilities in Ethiopia. 18th International AIDS Conference; 2010; Vienna. Abstract MOPE0871.

17. Johnson BT, Picho K, Hueda-Medina TB. Efficay of interventions with behavioral components for HIV prevention 18th International AIDS Conference; 2010; Vienna. Abstract WEPE0210.

18. Kapoor G, Le Tallec Y, Cohen J, Abebe Y. An analysis of current and projected resource requirements for second line ART scale up in Ethiopia. 18th International AIDS Conference; 2010; Vienna. Abstract TUPE0915.

19. Kerouedan D. [The Global Fund to fight HIV/AIDS, TB and Malaria 5-y: evaluation policy issues]. Bull Soc Pathol Exot. 2010;103:119-122.

20. Lamontagne E, Ventelou B, Arrighi Y, Greener R. Macroeconomic gains in responding to HIV: The investment case. 18th International AIDS Conference; 2010; Vienna. Abstract CDE1322.

21. Lemma W, Kiflie Y, Kiflie W, Santos EMd. Building Health Evaluation Capacity in Africa: A University Based Training Program in Ethiopia. The 2010 Annual Conference of the American Evaluation Association; 2010; San Antonio, TX, USA. Abstract No. 814.

22. Melese M, Kassa T, Kassie Y, Kellerman S. Measuring clinical HIV/AIDS standards of care: Using lot quality assurance sampling (LQAS) in Amhara, Ethiopia Regional State Health Centers. 18th International AIDS Conference; 2010; Vienna. Abstract THPE0618.

23. Mirkuzie AH, Morkve O. Trends in PMTCT service utilization in Addis Ababa, Ethiopia. 18th International AIDS Conference; 2010; Vienna. Abstract MOPE0265.

24. Muhammed AJ. A case-based approach for designing knowledge based system for National
HIV/AIDS Resource Center: The case of Warmline Consultation Service [MA thesis]. Dept of Public Management Policy: Addis Ababa University; 2010.

25. Negash S. Learning assessment of a videoconference-based training: Lessons from medical training between USA and Ethiopia. Information Technology for Development. 2010;6:121-231.

26. Shargie AB, Bekele R. Application of Bayesian Networks (BN) technology in predicting major factors behind poor ART adherence trends in Ethiopia - the case of SNNPR region. 18th International AIDS Conference; 2010; Vienna. Abstract no. CDB0143.

27. Shen AT, Lima V, Heung C, Palmer A, Montaner J, Hogg R, et al. Assessment of PEPFAR's impact on selected health system parameters in SubSaharan African countries. . 18th International AIDS Conference; 2010; Vienna. Abstract MOAE0101.

28. Shiferaw G, Abdallah H, Francis A-N. Ensuring the six rights through innovative approach in Ethiopia. 18th International AIDS Conference; 2010; Vienna. Abstract MOPE0903.

29. Stuer F. Achieving MDGs: Transformational capacity development and integrated programming. 37th Annual International Conference on Global Health; 2010; Washington, DC, USA. Abstract No. A6.

30. Tefera MA. Assessment of achievements and challenges of the implementation of health extension programme: The comparitive study of Goro and Weliso Woredas [MA thesis]. Dept of Management Policy: Addis Ababa University; 2010.

31. Teke GT. International assistance for combating HIV/AIDS: A case on PEPFAR's effect on medical doctors' attrition in Ethiopia [MA thesis]. Dept of Social Anthropology: Addis Ababa University; 2010.

32. Telake DS, Forsythe S, Emmart P, Tibebu S. A cost analysis of PEPFAR-funded orphan and vulnerable children programs in Ethiopia. 18th International AIDS Conference; 2010; Vienna. Abstract TPHE0862.

33. Tensou B, Araya T, Telake DS, Byass P, Berhane Y, Kebebew T, et al. Evaluating the InterVA model for determining AIDS mortality from verbal autopsies in the adult population of Addis Ababa. Trop Med Int Health. 2010;15:547-553.

34. Tessema B, Telake DS, Araya T. Epidemiology of AIDS mortality in Addis Ababa, Ethiopia. 18th International AIDS Conference; 2010; Vienna. Abstract CDC0246.

35. Thomas DY. Cookies and cokes: Clincial mentoring designs and approaches for ART scale 
up. 18th International AIDS Conference; 2010; Vienna. Abstract CDE1130.

36. Wako SK. The role of adult education in mainstreaming HIV/AIDS graduates' regular work: A case of Holeta ATVET College [MA thesis]. Dept of Adult and Livelong Learning: Addis Ababa University; 2010.

37. WHO, UNAIDS, UNICEF. Towards Universal Access: Scaling up Priority HIV/AIDS Interventions in the Health Sector, Progress Report 2010; September 2010.

38. Williams K. Integrating HIV/AIDS messages in teachings of the Ethiopian Church. 37th Annual International Conference on Global Health; 2010; Washington, DC, USA. Abstract No. G4.

39. Worku ZT. Media communication campaign in promoting free public discussion dialogues and debate about HIV/AIDS and sexuality related diseases [MA thesis]. Dept of Journalism and Communication: Addis Ababa University; 2010.

\section{Section 9. Diaspora Research}

This section includes studies on the characteristics and clinical course of HIV infection and opportunistic infections, treatment to AIDS and opportunistic infections, effects and outcomes associated with treatment, clinical and non-clinical care and supportive services provided to people living with HIV/AIDS.

1. Ahuja SD. The contribution of country of origin to the epidemiology, incidence and transmission of Mycobacterium tuberculosis in New York City, 2001-2008 [PhD thesis]. Dept of Epidemiology: Johns Hopkins University Bloomberg School of Public Health; 2010.

2. Barrett HR, Mulugeta B. Human Immunodeficiency Virus (HIV) and migrant "risk environments": The case of the Ethiopian and Eritrean immigrant community in the West Midlands of the UK. Psychol Health Med. 2010;15:357-369.

3. Bendayan D, Hendler A, Polansky V, Weinberger M. Outcome of hospitalized MDR-TB patients: Israel 2000-2005. Eur J Clin Microbiol Infect Dis. 2010.

4. Bendayan D, Littman K, Polansky V. Active tuberculosis and human immunodeficiency virus co-infection in Israel: A retrospective study. Isr Med Assoc J. 2010;12:100-103.

5. Fulton D, Kline S. Tuberculosis at the University of Minnesota Medical Center, 2000 to 2006: A brief report. Minn Med. 2010;93:50-52.

6. Guillou-Debuisson C, Salanne S, Marechal C, Laporte E, Claudet I, Grouteau E. [Osteoarticular tuberculosis: A differential diagnosis of idiopathic juvenile arthritis]. Arch Pediatr. 2010;17:15531558.

7. Hume SC, Aboltins CA, Thursky KA, Daffy JR, Stanley PA. Visceral leishmaniasis due to
Leishmania donovani in a patient with advanced HIV infection. Med J Austral. 2010;192:474-475.

8. Johnson AS, Hu X, Dean HD. Epidemiologic differences between native-born and foreignborn black people diagnosed with HIV infection in 33 U.S. States, 2001-2007. Public Health Reports. 2010;124 61-69.

9. Lemoh CN, Baho S, Grierson J, Hellard M, Street A, Biggs BA. African Australians living with HIV: a case series from Victoria. Sex Health. 2010;7:142148.

10. Rubin L, Inbar SN, Rishpon S. Breastfeeding patterns among Ethiopian immigrant mothers, Israel, 2005-2006. Israel Med Assoc J. 2010;12:657-661.

11. Sagbakken M, Bjune GA, Frich JC. Experiences of being diagnosed with tuberculosis among immigrants in Norway - Factors associated with diagnostic delay: A qualitative study. Scand J Publ Health. 2010;38:283-290.

12. Smolyakov R, Riesenberg K, Borer A, Saidel-Odes L, Schlaeffer F. Tuberculosis in African Refugees in southern Israel. 50th Interscience Conference on Antimicrobial Agents and Chemotherapy; 2010; Boston, MA, USA. Abstract No. P-1126.

13. Soffer M, Ajzenstadt M. Stigma and otherness in the Israeli media's mirror representations of illness. Qual Health Res. 2010;20:1033-1049.

14. Treviño A, de Mendoza C, Benito R, Caballero E, Aguilera A, Ortiz de Lejarazu R, et al. Molecular epidemiology, clinical manifestations and public health implications of HTLV-1 infection in Spain. 18th International AIDS Conference; 2010; Vienna. Abstract CDA0012.

\section{Section 10. Selected Websites Featuring HIV/AIDS in Ethiopia}

1. Federal HIV/AIDS Prevention and Control Office of Ethiopia: http://hapco.gov.et/

2. Center for International Health of the University of Bergen, Norway (also access to the Ethiopian Journal of Health Development): http://ejhd.uib.no/

3. Christian Relief and Development Association: www.crdaethiopia.org

4. Ethiopian AIDS Resources Center: http://www. etharc.org

5. Family Health International: http://www.fhi.org/en/ CountryProfiles/Ethiopia/index.htm

6. Johns Hopkins University Center for Clinical Global Health Education: http://ccghe.jhmi.edu/CCG/ country/ethiopia/

7. People to People Organization: http://www. peoplepeople.org/

8. Save the Children: http://www.savethechildren. net/ethiopia/

9. United Nations Children's Fund (UNICEF): http://www.unicef.org/ethiopia/hiv_aids_464.html 
10. United Nations Development Programme (UNDP) http://www.et.undp.org/index.php?option=com_proj ect\&id $=13$

11. United Nations Educational, Scientific and Cultural Organization

(UNESCO):

http://hivaidsclearinghouse.unesco.org/search/format liste.php?lang=en\&ret=topics.php\&Chp2=Ethiopia

12. United Nations Joint Program on AIDS (UNAIDS): http://www.unaids.org/en/CountryResponses/Countri es/ethiopia.asp

13. United States Centers for Disease Control and Prevention (CDC): http://www.cdc.gov/globalaids/ countries/Ethiopia/

14. AIDS Portal: http://www.aidsportal.org/overlay details.aspx? $\mathrm{nex}=20$

15. University of California, San Francisco HIV In Site: http://hivinsite.ucsf.edu/global?page $=$ cr09-et-00

16. Network of Ethiopian Professionals in the Diaspora (NEPID): http://www.nepid.org/
17. The International Technical Training and Education Center on HIV (I-TECH) of the University of Washington: http://www.go2itech.org/itech?page= co-03-00

18. The International Center for AIDS Care and Treatment Programs (ICAP) at Columbia University's Mailman School of Public Health: http:/www.columbia-icap.org/wherewework/ ethiopia/index.html

19. World Health Organization: http://www.who.int/ countries/eth/en/

20. United States Agency for International Aid: http://www.usaid.gov/our_work/global_health/aids/ Countries/africa/ethiopia.html

21. 18th International AIDS Conference, Vienna, 2010: www.aids2010.org or, for abstracts, http://www. iasociety.org/Default.aspx?pageId=7 